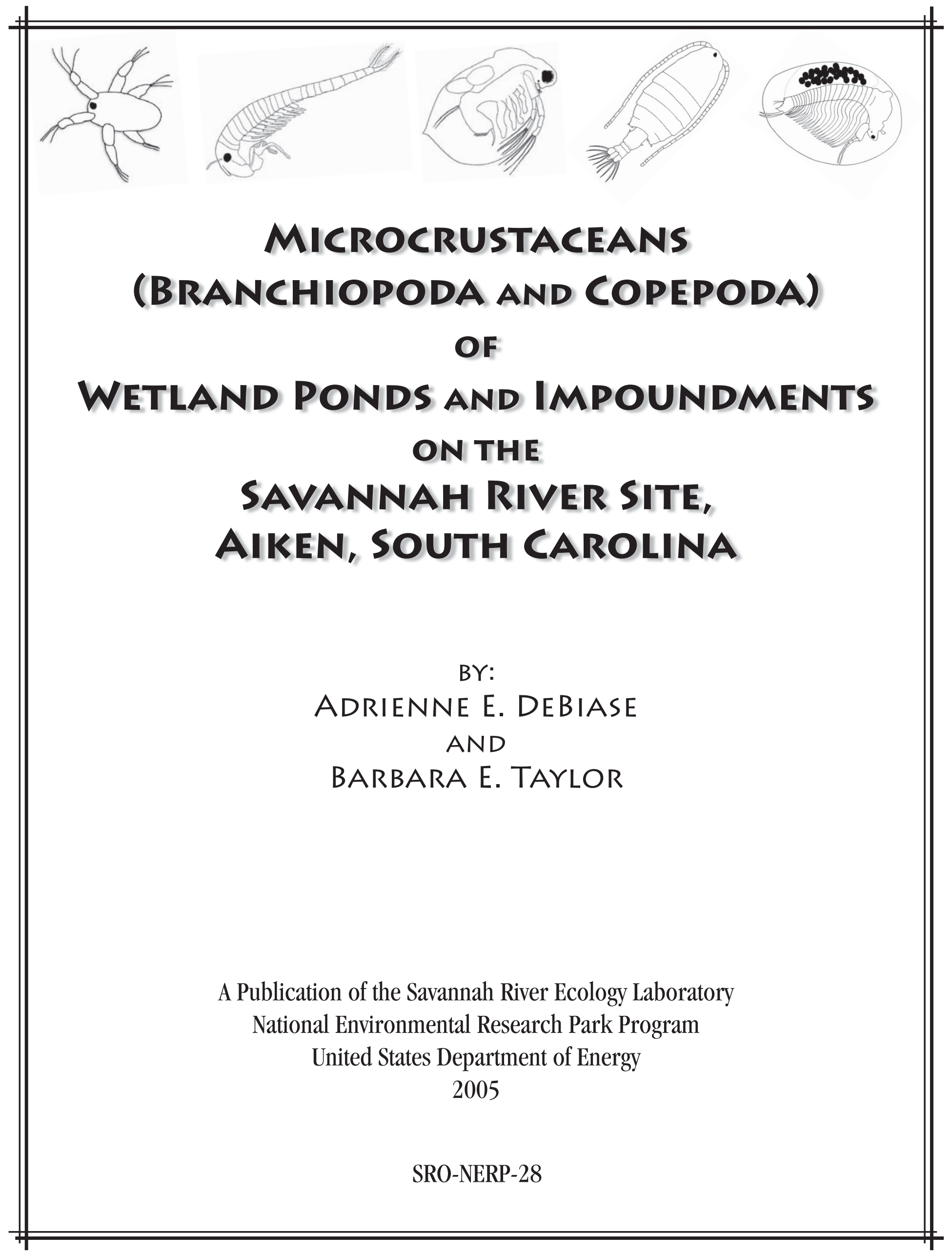




\section{MICROCRUSTACEANS (BRANCHIOPODA AND COPEPODA) OF WETLAND PONDS AND IMPOUNDMENTS ON THE SAVANNAH RIVER SITE, AIKEN, SOUTH CAROLINA}

BY:

ADRIENNE E. DEBIASE

AND

BARBARA E. TAYLOR

A Publication of the Savannah River Site

National Environmental Research Park Program

SRO-NERP-28

2005

Prepared under the auspices of

The University of Georgia

Savannah River Ecology Laboratory

P.O. Drawer E

Aiken, South Carolina

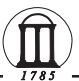

The University of Georgia

$\overline{\text { Savannah River Ecology Laboratory }}$ 


\section{A publication of the Savannah River Site National Environmental Research Park Program Publication number: SRO-NERP-28}

Printed: 15 February 2005

Layout and design: Laura L. Janecek

Copies may be obtained from: The Savannah River Ecology Laboratory

P.O. Drawer E

Aiken, SC 29802 


\section{CONTENTS}

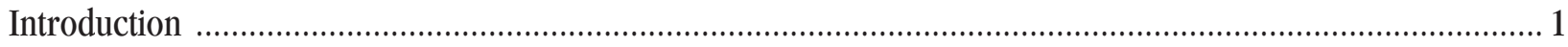

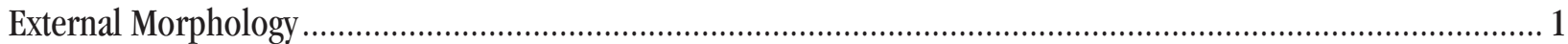

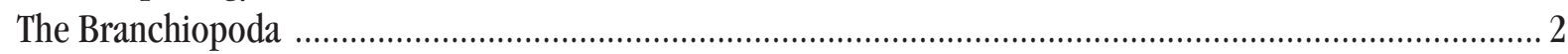

The Large Branchiopoda: Laevicaudata and Spinicaudata .............................................................. 2

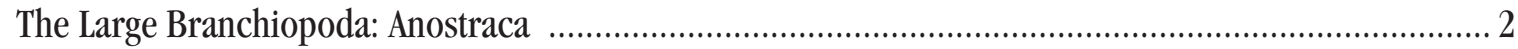

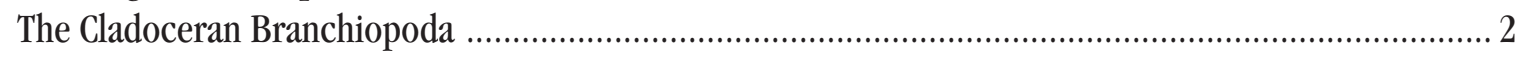

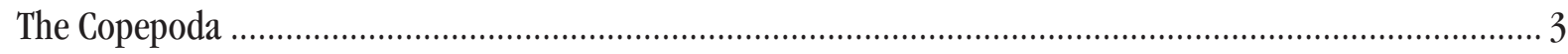

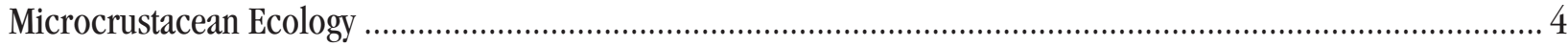

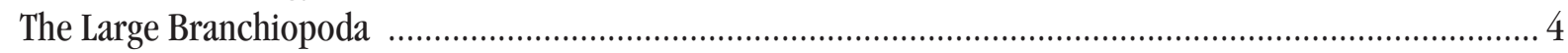

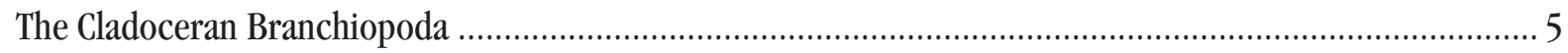

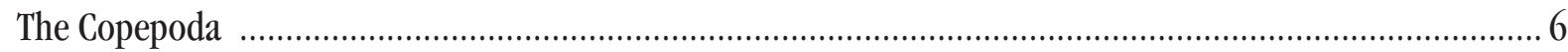

Study Area

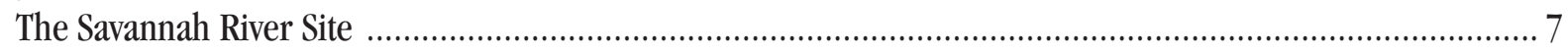

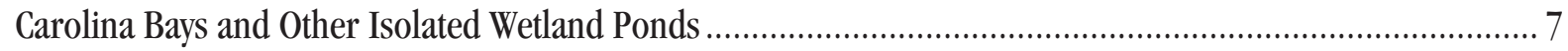

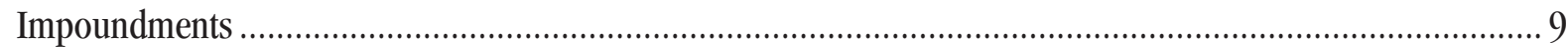

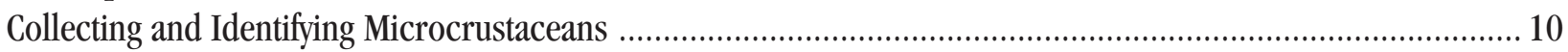

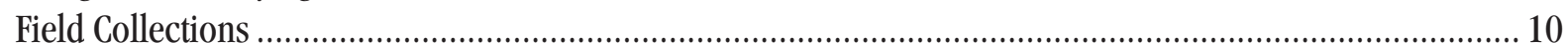

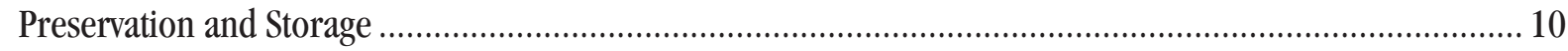

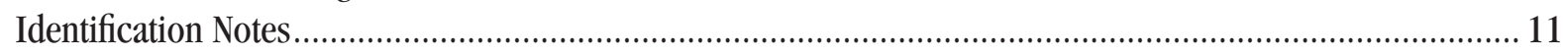

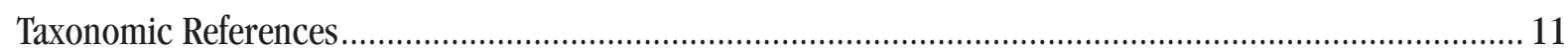

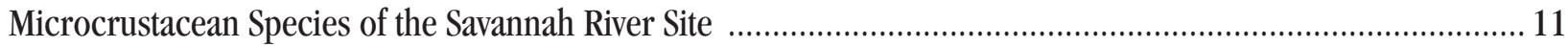

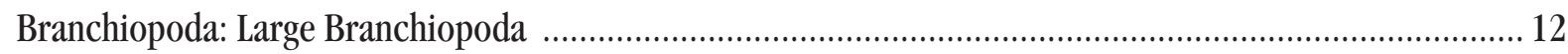

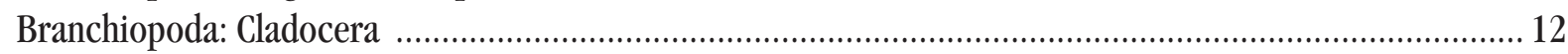

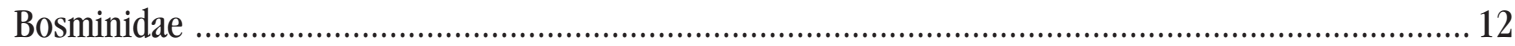

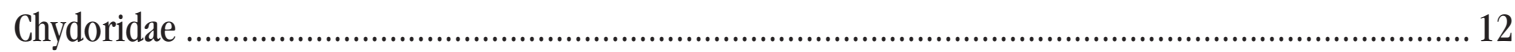

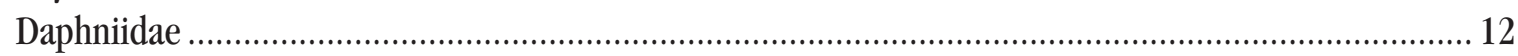

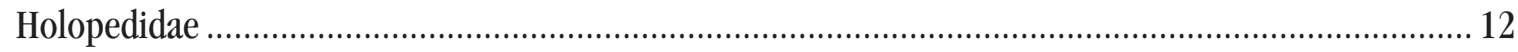

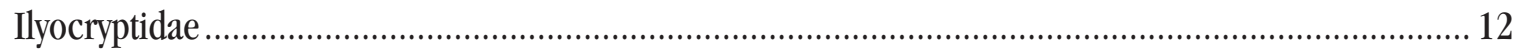

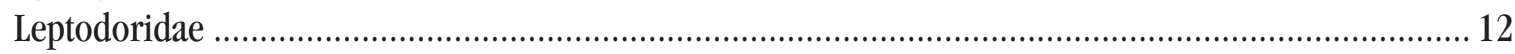

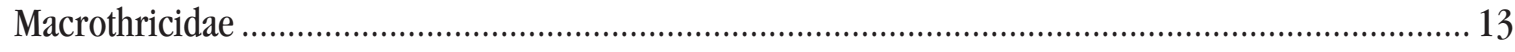

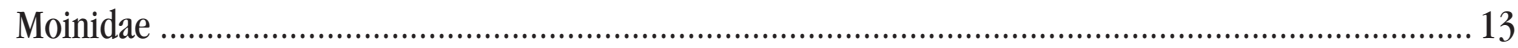

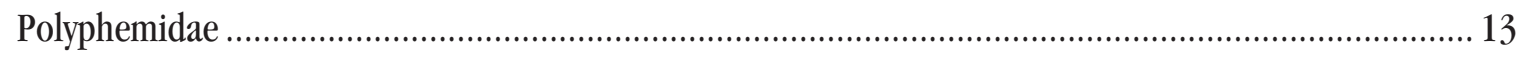

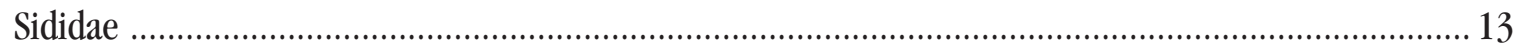

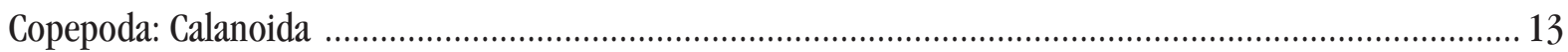

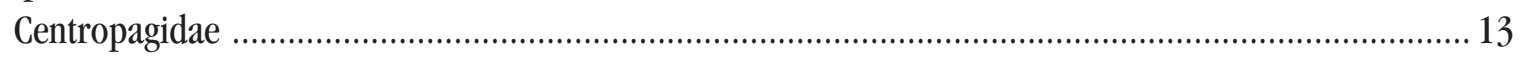

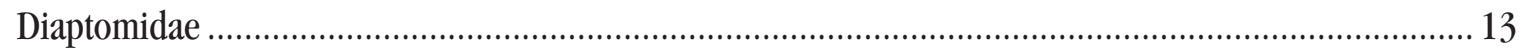

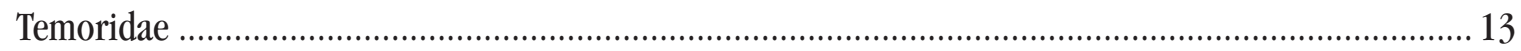

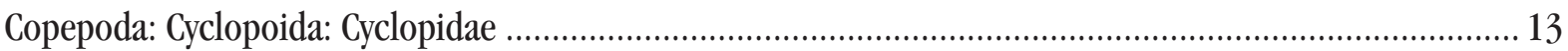

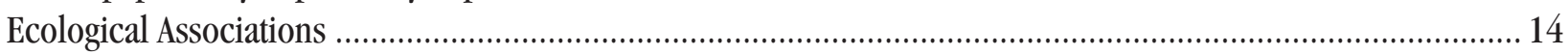

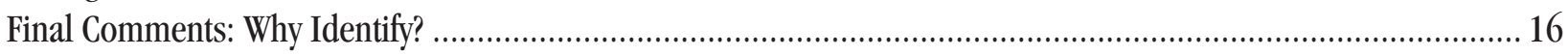

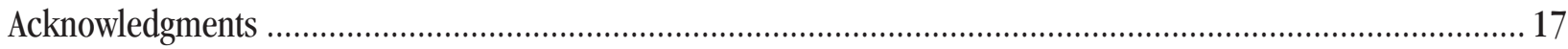

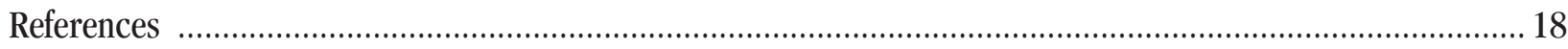




\section{LIST OF FIGURES}

Figure 1. External morphology of the nauplius of a calanoid copepod ......................................................... 1

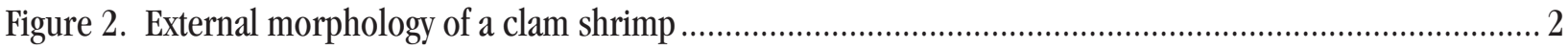

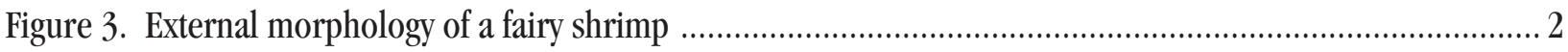

Figure 4. External morphology of a cladoceran ...................................................................................... 3

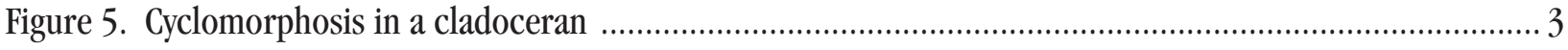

Figure 6. External morphology of a calanoid copepod ........................................................................ 3

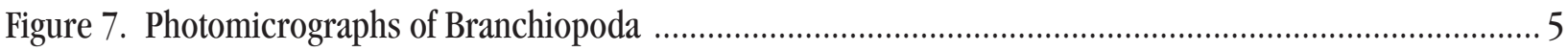

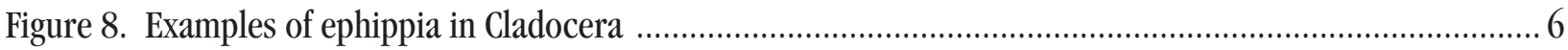

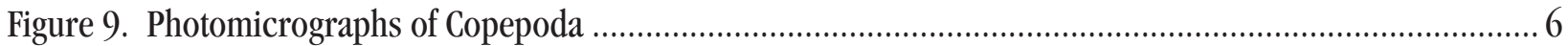

Figure 10. Map of wetlands and water bodies of the Savannah River Site ....................................................... 8

Figure 11. Species richness in response to hydrologic class ...................................................................... 14

Figure 12. Hydrologic ranges of branchiopod and copepod species ......................................................15-16

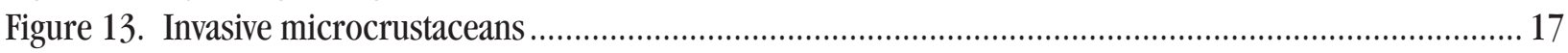

\section{LIST OF APPENDICES}

Appendix A. Branchiopod, cyclopoid, and calanoid copepods species from the Savannah River Site ............... 25

Appendix B. Notes on undescribed species of cladocerans and copepods from the Savannah River Site ........... 31 


\section{INTRODUCTION}

The United States Department of Energy's Savannah River Site (SRS) in Aiken, Allendale, and Barnwell Counties, South Carolina, contains an abundance of freshwater wetlands and impoundments. Four large impoundments, as well as several small, abandoned farm and mill ponds, and about 400 Carolina bays and other small, isolated depression wetland ponds are located within the $893 \mathrm{~km}^{2}$ area of the SRS. Crustaceans of the orders Branchiopoda and Copepoda are nearly ubiquitous in these water bodies. Although small in size, these organisms are often very abundant. They consequently play an important trophic role in freshwater food webs supporting fish, larval salamanders, larval insects, and numerous other animals, aquatic and terrestrial.

Microcrustacean distributions in the southeastern United States are relatively unstudied. The SRS is an exception. Dorothy Berner conducted the first systematic study of the microcrustaceans on the SRS during the late 1970's, producing a key to the Cladocera of Par Pond (Berner 1982). A survey of Branchiopoda and Copepoda in 23 Carolina bays and other isolated depression wetland ponds conducted in 1987 by Mahoney et al. (1990) demonstrated that these ponds contain some of the most species-rich microcrustacean communities of any temporary ponds in the world. Other published studies focused on species distributions include reports on temorid copepods of impoundments (DeBiase and Taylor 1993), fairy and clam shrimps of the wetland ponds (DeBiase and Taylor 2003), and a description of a new species of calanoid copepod common in wetland ponds of the SRS (DeBiase and Taylor 1997). Many other studies have contributed to knowledge of the role that microcrustaceans play in aquatic communities of the SRS (overviews in Wike et al. 1994, Taylor et al. 1988, Taylor et al. 1999).

This report provides an introduction to the free-living microcrustaceans of lentic water bodies on the SRS and a comprehensive list of species known to occur there. Occurrence patterns are summarized from three extensive survey studies, supplemented with other published and unpublished records. In lieu of a key, we provide a guide to taxonomic resources and notes on undescribed species. Taxa covered include the orders Cladocera, Anostraca, Laevicaudata, and Spinicaudata of the Subclass Branchiopoda and the Superorders Calanoida and Cyclopoida of Subclass Copepoda. Microcrustaceans of the Superorder Harpacticoida of the Subclass Copepoda and Subclass Ostracoda are also often present in lentic water bodies. They are excluded from this report because they have not received much study at the species level on the SRS.

\section{EXTERNAL MORPHOLOGY}

Crustaceans, like nearly all arthropods, have a hard, flexible exoskeleton and a segmented body plan. A pair of jointed appendages or other structures is typically associated with each segment. Most species have a single or pair of compound eyes. Compared with many other arthropods, crustaceans have reduced segmentation, which in some groups is nearly lost. Crustaceans are also distinguished by five pairs of head appendages, including two pairs of antennae, a pair of mandibles, and two pairs of maxillae. Their appendages are typically biramous (branched into two parts). They are modified to serve many different functions, including feeding and locomotion. In larger species, gills are typically associated with the appendages. They are usually absent in the very small species, such as those covered in this report.
Many crustacean species, including copepods, clam shrimps, and fairy shrimps, produce a free-swimming larva called a "nauplius" (Fig. 1). The earliest stage nauplius consists of an unsegmented body and three

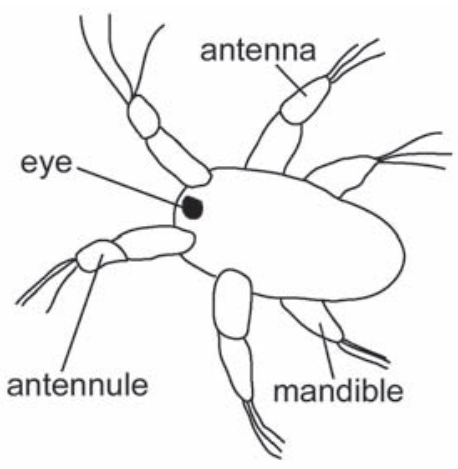

Figure 1: External morphology of the nauplius of a calanoid copepod. pairs of appendages: the antennules, the antennae, and the mandibles. A single eye is also present on the front of the head, but no oral aperture is present (vitelline reservoirs provide nourishment at this stage). Additionalseg- 
ments and their associated appendages develop over the course of successive molts.

\section{THE BRANCHIOPODA}

The principal characteristic common to all Branchiopoda is their flattened, leaf-like thoracic legs (also known as phyllopods). These appendages are edged with setae and are not distinctly segmented. The Branchiopoda generally have the typical five pairs of head appendages that typify the Crustacea. All families have similar mouthparts consisting of a pair of simple, unsegmented mandibles. All have a labrum, but the labium is present only in the Notostraca. The mandibles are generally strongly chitinized. The first and second maxillae may be present as small scalelike structures or they may be absent. A pair of spines or claws is present on the last body segment.

The Large Branchiopoda: Laevicaudata and Spinicaudata (Fig. 2) - The clam shrimps (formerly classified together as Conchostraca) range in size from $2-17 \mathrm{~mm}$ in the Spinicaudata and 4-7 $\mathrm{mm}$ in the Laevicaudata. In the Spinicaudata, the body is completely enclosed in a carapace that resembles a clam shell. However, in the Laevicaudata, the head is free. The carapace may be yellow, orange, or brown. The number of trunk segments varies by order. The Spinicaudata have ten to 32 segments, each bearing a pair of appendages. The trunk terminates in a strongly chitinized, armored postabdomen that are much like that of the Cladocera. The females of Laevicaudata have 12 appendage-bearing segments, while males have only ten. Both Spinicaudata and Laevicaudata have one pair of biramous swimming antennae, with each ramus consisting of 15 segments.

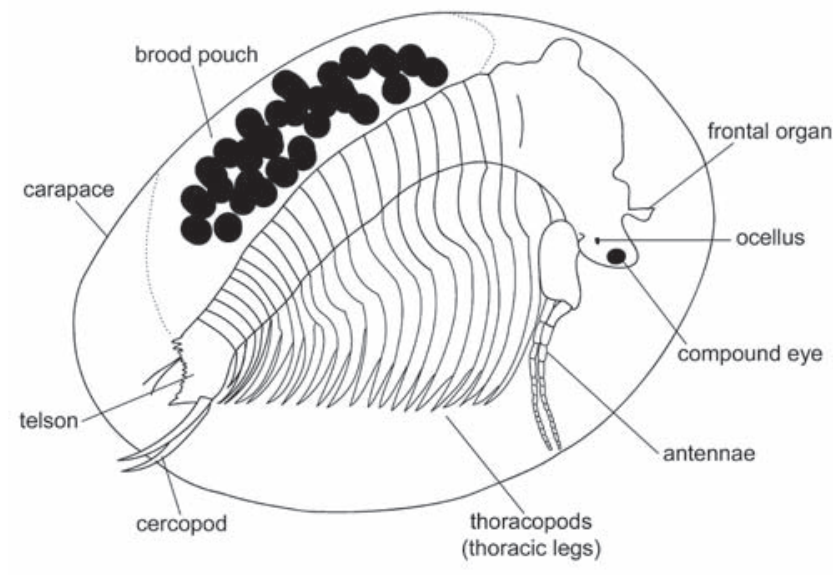

Figure 2. External morphology of a clam shrimp.
The Large Branchiopoda: Anostraca (Fig. 3)Anostracans range in length from 10-70 mm (excluding cercopods). The body is cylindrical and segmented, with a distinct abdomen and thorax. The body lacks a carapace. The head consists of five somites, and a pair of stalked compound eyes is located dorsally. The antennae articulate with the head near the base of the eye stalk and are filament-like with generally indistinct segmentation. The antennules usually have two segments in females, while they are highly modified and often branched in the males. The male antennules are an important taxonomic characteristic. The anostracan thorax usually has 11 segments, but can have up to 19, each bearing a pair of appendages. The 8-9 segmented abdomen is free of appendages and terminates into a weakly sclerotised postabdomen with a pair of expansions called cercopods.

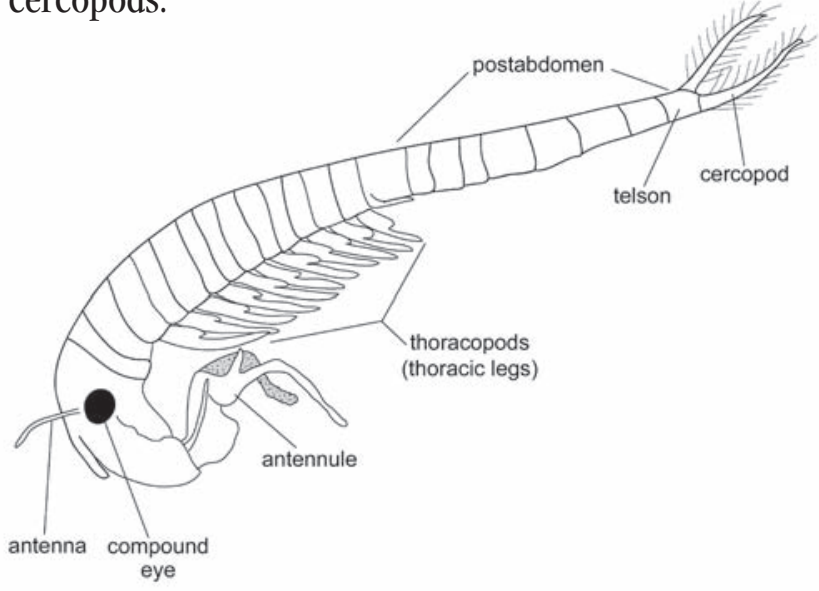

Figure 3. External morphology of a fairy shrimp.

The Cladoceran Branchiopoda (Fig. 4)_-Adult Cladocerans, which include the commonly known Daphnia, are generally $0.2-5 \mathrm{~mm}$ long. A majority are less than $2 \mathrm{~mm}$, but Leptodora can reach $18 \mathrm{~mm}$. Except in the predatory orders Haplopoda and Onychopoda, the thorax, its four to six legs, and the abdomen are generally enclosed by a carapace that ranges in color from transparent to yellowish to black. In Daphnia, the carapace has a terminal tail spine. The carapace serves as a brood chamber. The abdomen is reduced and has no limbs. The terminal end, called the postabdomen, is laterally compressed and generally ends in a pair of claws. The shape and armature of the postabdomen and the claws are important taxonomic characteristics. In the predatory orders, the thoracic legs and abdomen are exposed, and eggs develop in a dorsal brood chamber. 


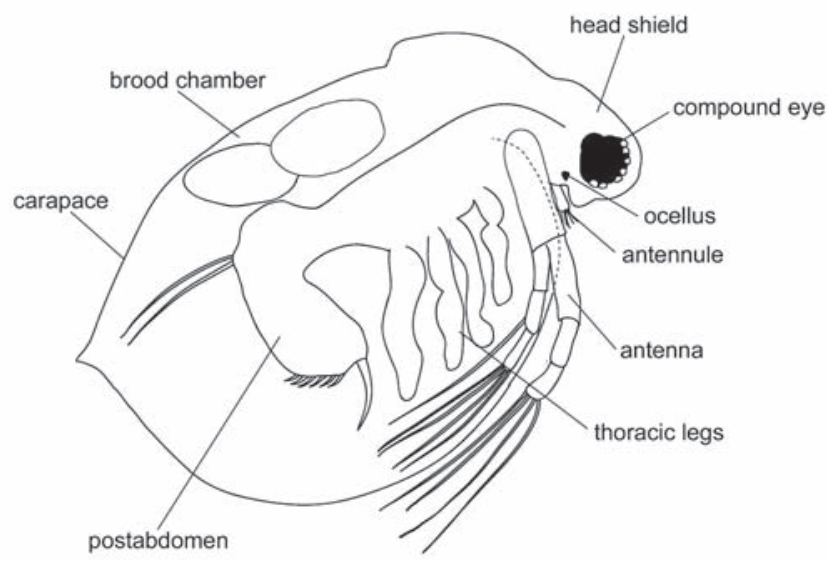

Figure 4. External morphology of a cladoceran.

The head is always separate and is covered by a head shield, except in the Leptodoridae. Cladocerans have a single central compound eye, as well as two pairs of antennae. Some species also have a pair of small eyespots or ocelli. The first pair of antennae are often called antennules and are small and usually of one segment. The antennules show sexual dimorphism, and those of the male are used for taxonomic identification. The second pair are generally called antennae, and are used for swimming. They vary by species in numbers of segments and setae, as well as armament.

Cladocera can exhibit drastic variation in shape from generation to generation. This phenomenon, called cyclomorphosis because it often occurs on a
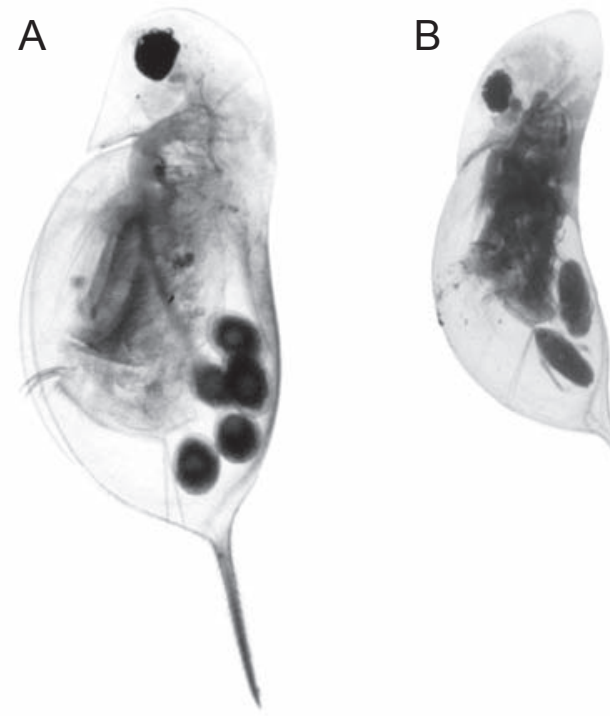

Figure 5. An example of cyclomorphosis in the cladoceran Daphnia laevis. [A] shows a normal morph, typical of cool, foodrich water in early spring; [B] shows helmeted morph, typical of warm, food-poor water in late spring. regular cycle, can be extreme enough to confuse the unacquainted observer into believing that the two different morphs belong to different species. Morphs may differ in lengths of tail spines or other projections or presence of crests ("helmets") or even in the shape of the body (Fig. 5). Cyclomorphosis is best known in the Daphniidae and Bosmina, but it has also been observed in littoral chydorids. Changes in the chydorids are often less conspicuous, including such differences as a relative change in the size of the head or some other body part. Induction of cyclopmorphosis has been attributed to photoperiod, predation, and temperature (see Kerfoot 1980 for review).

\section{THE COPEPODA}

Most free-living freshwater copepods (Fig. 6) are small, \#1 mm in length (excluding furcal setae), but some are up to 4-5 mm long. The body generally consists of 16 somites (body segments). The first six are fused to form the cephalosome, while the thoracic and urosomal segments comprise the remaining ten somites. The cephalosome and the thorax comprise the cephalothorax. The numbers of apparent somites of the cephalothorax vary by species due to fusion. Many copepods are transparent,

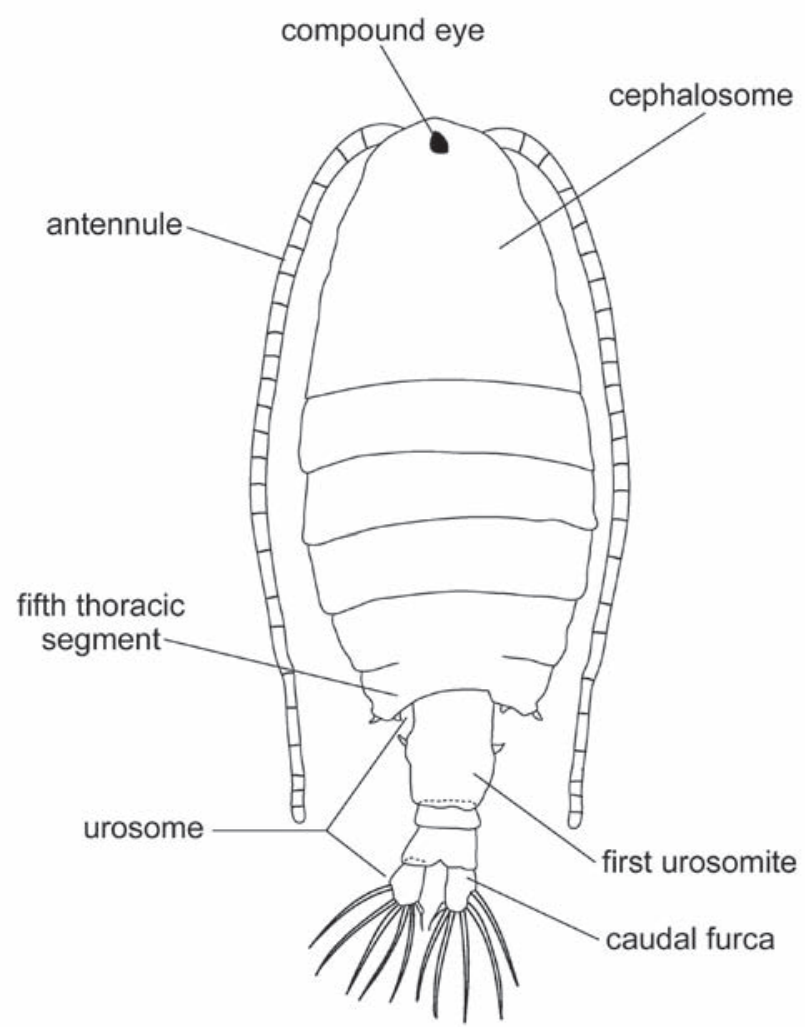

Figure 6. External morphology of a calanoid copepod (dorsal view). In life, the antennules are normally extendedperpendicular to the body. 
sometimes with a brown or green tint. Many temporary pond and high mountain calanoids accumulate pigments which give them a red, orange, or blue color.

The typical copepod cephalosome has a pair each of antennae and antennules, along with the standard crustacean oral appendages, all of which are welldeveloped. The segmentation and armament of one or both antennules are modified in the males. Copepods have five pairs of legs. The somite that bears the first pair of legs is fused to the cephalosome. The remainder are found on the thoracic segments. The fifth pair is modified for mating. The modifications vary by species and sexes. The abdominal or urosomal segments have no appendages, but a genital complex is present on the first urosomite. The last urosomite ends in a furca consisting of two generally symmetrical, setae-adorned rami.

The three superorders of free-living freshwater copepods, Calanoida, Cyclopoida, and Harpacticoida, can easily be distinguished by body shape and antennule length.

The calanoid cephalothorax is torpedo-shaped. Their antennules are usually 25 segments or fewer, and are usually as long or longer than the body. The female antennules are symmetrical, while the right male antennule is modified (see Fig. 9C) for grasping females during mating (Dussart and Defaye 2001). The fifth thoracic leg of the males is highly modified, and the shapes and armament varies by species. In calanoid females the symmetry and armament of both the last thoracic segment and the urosome varies by species. Females carry eggs in one external sac in some families, while others deposit eggs directly to the sediment.

Cyclopoid copepods are fusiform in shape. They have six- to seventeen-segmented antennules, depending on the species. Both are modified in the males, and in both sexes, they rarely extend beyond the midpoint of the body. Like the calanoids, the fifth legs are modified. However, unlike the calanoids, they are similar between the sexes. The urosomite of the cyclopoids bears a reduced leg-like structure, which in females is represented by two small protuberances and a seta. They are better developed in males and have two setae and a spine. Cyclopoids have two external egg sacs.

Harpacticoid copepods are cylindrical in shape and have very short antennules of only six to nine segments. As with the cyclopoid copepods, the male antennules are modified. They are geniculated (elbowed) between two of the distal segments. Sometimes the apical portion is modified to form a stout claw. Body segmentation also varies by sex in adults. The females of most of the genera have nine segments, while males have ten segments. The genital and first abdominal segments are fused in females. Females carry eggs in a pair of external sacs.

\section{MICROCRUSTACEAN ECOLOGY}

The Branchiopoda (Fig. 7) and Copepoda are common and abundant inhabitants of surface waters, especially in areas of lower water flow, such as lakes, ponds, reservoirs, ephemeral ponds and ditches. Although branchiopods and copepods often inhabit the same water bodies, they differ in their feeding preferences, life histories, and even in the microhabitats within the water body.

\section{THE LARGE BRANCHIOPODA}

The large, non-Cladoceran Branchiopoda are predominately freshwater species and they occur almost exclusively in ephemeral ponds and in some shallow, fishless lakes (Williams 1987, Dodson and Frey 1991) where they are one of the most characteristic faunal components. However, some anostracans of the genus
Artemia (brine shrimps) occur in inland saline lakes. Brine shrimps can tolerate conditions ranging from slightly brackish to hypersaline (D'Agostino 1980, Dodson and Frey 1991). A few clam shrimp species are also known from oligohaline waters (Dumont and Negrea 2002). Furthermore, some anostracan species occur in high mountain lakes and rivers (Bohonak and Whiteman 1999, Dumont and Negrea 2002).

Among the clam shrimps, the Spinicaudata spend most of their life on or in the bottom mud, while the Laevicaudata live among the vegetation. The anostracans spend much of their time in the open water, but they may occasionally descend to the bottom to feed. Phyllopods are generally short-lived with a maximum life span of 4-5 months for 
A

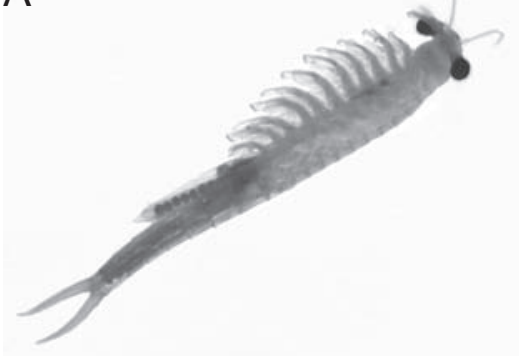

D

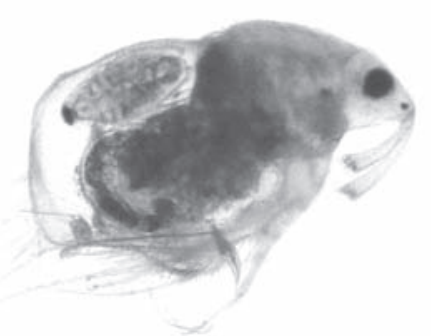

B

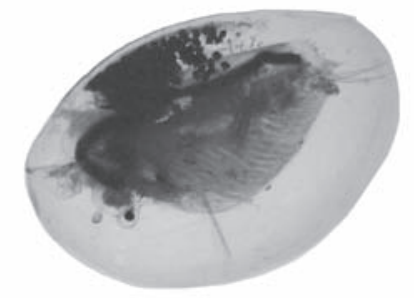

E

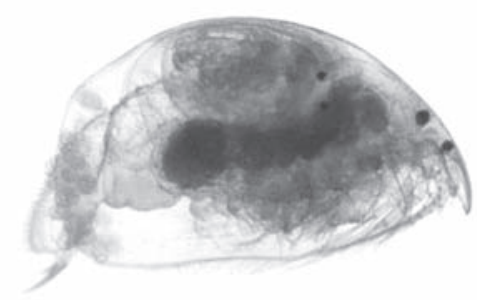

C
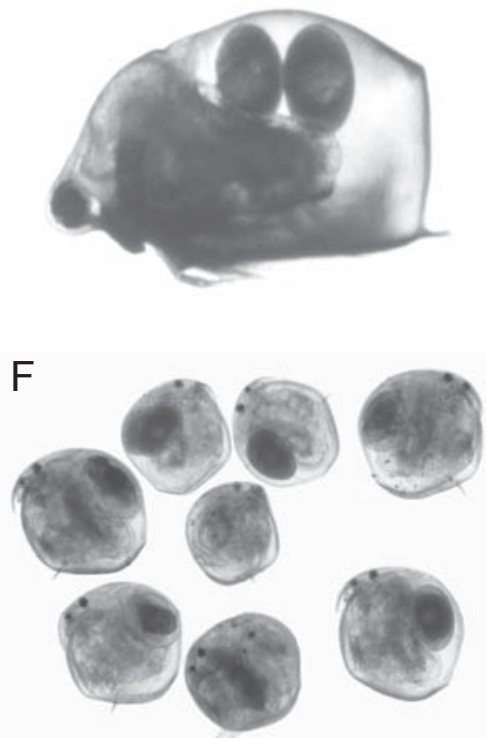

Figure 7. Photomicrographs of Branchiopoda: [A] Anostraca, [B] Spinicaudata, [C] Cladocera (Daphniidae) Scapholeberis, [D] Cladocera (Macrothricidae) Acantholeberis, [E] Cladocera (Chydoridae: Aloninae) Alona, [F] Cladocera (Chydoridae: Chydorinae) Chydorus.

species in cold waters (Thiéry 1996) and often much shorter for warm water species.

Anostracans and conchostracans, like the cladocerans, arepredominatelyfilterfeeders, although some anostracan species are raptorial predators who supplement their diets with algal food. The filter-feeding species consume whatever detritus particles, bacteria, algae, and small animals are entrained in their feeding currents and can be easily handled by their mouthparts (Kaestner 1970, Bernice 1971, Fryer 1983).

Phyllopodous branchiopods normally complete only one generation per wet phase. All groups produce only resting eggs; however, the means of production of these eggs varies. The anostracans reproduce only sexually, while clam shrimps can be obligately sexual, hermaphroditic, or parthenogenetic. Notostracans are either male or hermaphrodite. Hermaphrodites may mate with males, or they may self-fertilize.

Female anostracans generally carry their eggs in an external sac and release them at molting. Conchostracans retain their eggs within the carapace and eventually shed them. The phyllopodous branchiopods hatch as nauplii or metanauplii (Anderson 1967, Daborn 1976, Fryer 1983).

\section{THE CLADOCERAN BRANCHIOPODA}

The Cladocera are found largely in freshwater, although, a considerable number of species occur in brackish and marine waters. Although cladocerans are usually associated with large, deep, permanent lakes, they are also abundant in smaller water bodies, including temporary ponds. They exploit both planktonic and littoral habitats. Their life spans range from about 15 days for the chydorid Monospilus (Frey 1987) to 4-5 months for other species (Dumont and Negrea 2002). Most planktonic cladocerans are filter feeders, consuming algae, bacteria (Porter et al. 1983, Lampert 1987), and small particles of detritus, protozoans, and small rotifers (Porter 1973, Burns and Gilbert 1986, Wickham and Gilbert 1991, Jack and Gilbert 1994, Dumont and Negrea 2002). A few species, including the daphniid Scapholeberis, also feed on the underside of the surface water film, collecting hyponeustonic algae (Dumont and Negrea 2002). Although they collect a wide variety of food items in their filtering currents, the planktonic cladocerans are selective in what they actually consume. Their food preferences can influence their algal community structure and succession (Porter 1977).

Not all planktonic cladocerans are filter-feeders. Two species found on the SRS, Polyphemus pediculus and Leptodora kindti, are raptorial predators, whose prey consists mainly of smaller cladocerans, rotifers, protozoans, and even whole cyclopoid copepods 
(Monakov 1972, Edmondson and Litt 1987, Lehman 1987).

Littoral cladocerans consume the same types of items as their planktonic counterparts. They obtain their food by filter feeding or by scraping from vegetation, rocks, and other substrates (Fryer 1968, Smirnov 1971). The chydorid Pseudochydorus globosus feeds on decomposing microcrustaceans (Dumont and Negrea 2002).

Most cladocerans reproduce asexually during at least part of the year. Parthenogenetic females produce diploid, asexual female eggs which develop in a brood chamber within the female's carapace. The neonates are expelled just before the mother molts. After molting, she extrudes another set of eggs into the brood pouch. The offspring are usually all female. The newly released cladocerans resemble adults in body plan.

Sexual reproduction in cladocerans can occur in response to high population density, food limitation, or other adverse conditions. First, clutches of male and female eggs are produced. Then females produce haploid eggs, which are fertilized. These eggs can remain dormant for extended periods. In many species, the resting eggs are protected by a modification of the carapace called an "ephippium" (Fig. 8). An ephippium contains one or two eggs, depending on the species. Ephippia are shed at molting. They may sink to the sediments, where they remain until proper conditions stimulate hatching. Or, they may float, and some may stick to the fur or feathers
A

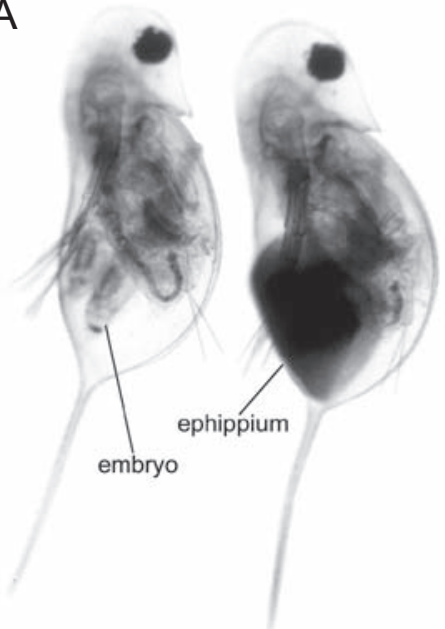

B

Figure 8. Examples of normal and resting eggs in Cladocera: [A] Daphnia laevis normal (left) and resting (right) eggs; note ephippium forming in carapace; [B] ephippium from Simocephalus, resting egg is enclosed.

of a passing animal to be dispersed elsewhere. The ephippia are resistant to drying and freezing. They can withstand the passage through the digestive tracts of birds or fishes, and they are light enough to be transported by wind. Offspring hatching from resting eggs are generally asexual females. Dodson and Frey (1991) and Dumont and Negrea (2002) provide more details of cladoceran life histories.

\section{THE COPEPODA}

The Copepoda (Fig. 9) is an enormous group, encompassing vast numbers of species and individuals in freshwater, brackish, and marine habitats. They may be the most abundant multi-cellular organisms on
A

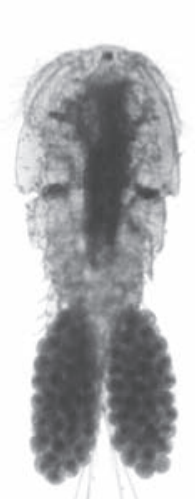

B

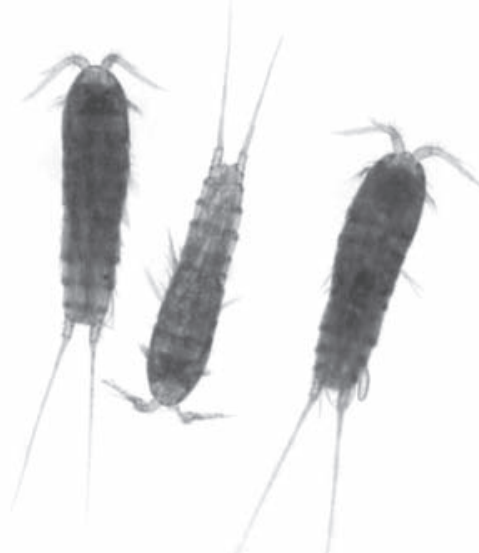

C

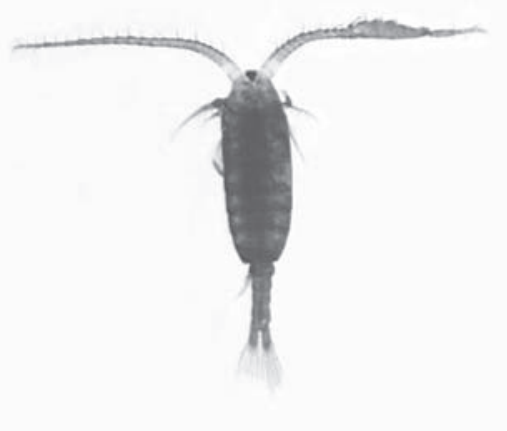

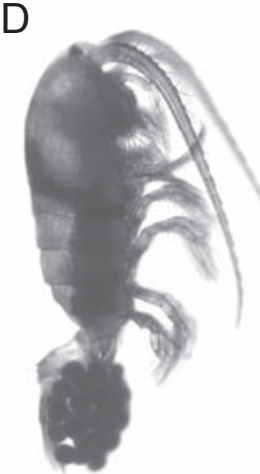

Figure 9. Photomicrographs of Copepoda: [A] Cyclopoida, female, [B] Harpacticoida, [C] Calanoida: Diaptomidae, male, dorsal view, [D] Calanoida: Diaptomidae, female, lateral view. 
Earth. Most copepod species occur in either marine or freshwater habitats, but some brackish water species do occur in freshwater. Eurytemora affinis, a coastal species, has been reported in freshwater lakes and rivers throughout much of the United States (see DeBiase and Taylor 1993 for first arrival on the SRS and Lee 1999 for recent freshwater distributions in North America). The overwhelming majority of the calanoid copepods are planktonic (Hutchinson 1967). The freshwater calanoid copepod Osphranticum labronectum, and many cyclopoid copepod species, occur primarily in littoral and benthic habitats.

Most calanoid copepods feed on mainly on planktonic algae, bacteria, and detritus, which they sweep into their mouths using a complex set of appendages (Vanderploeg and Paffenhöfer 1985). Larger species such as Aglaodiaptomus stagnalis may also consume small invertebrates (Williamson 1983, 1986; AED pers. obs.). Some cyclopoid copepods also feed mainly on algae, but others prey on small invertebrates, such as protozoans, rotifers, copepod nauplii, and copepodids, cladocerans, and dipteran larvae (Fryer 1957).
Copepods reproduce only sexually, and most species carry the eggs in external sacs. Calanoids have one egg sac, while cyclopoids and harpacticoids have two. Eggs hatch as nauplii, and undergo successive molts, passing through six naupliar stages, five copepodid stages, and an adult stage. Most calanoid species normally make subitaneous eggs, which begin to develop immediately. Some can also make resting eggs to avoid unfavorable conditions. A few species may produce both subitaneous and resting eggs in one system, but only resting eggs in others (Roff 1972). Some temporary pond calanoids, such as Aglaodiaptomus stagnalis, produce only resting eggs, which require a specific time window and hydrologic conditions for hatching (Taylor et al. 1990). Like the cladoceran ephippia, copepod resting eggs can withstand extended periods of dormancy, and they may also be a means of dispersal. Cyclopoid copepods produce only subitaneous eggs. To withstand poor conditions, some species can undergo encystment and diapause during late copepodid stages (Elgmork 1967, 1986, Elgmork and Nilssen 1978, Williams-Howze 1997).

\section{STUDY AREA}

THE SAVANNAH RIVER SITE

In 1951, the United States Department of Energy began construction on an $893 \mathrm{~km}^{2}$ nuclear production facility $32 \mathrm{~km}$ south of Aiken, South Carolina. The land was purchased during 1950. The site, now known as the Savannah River Site (SRS; Fig. 10), was closed to public access in 1952 and remains closed to date. The SRS is situated in the Upper Atlantic Coastal Plain physiographic region. It is located along the Savannah River in Aiken and Barnwell Counties, with an additional corridor along Lower Three Runs Creek in Allendale County. The SRS lies in two physiographic subregions. The north and central SRS lie on the upland Aiken Plateau, which is characterized by well-drained sandy soils. Elevations range from 80-120 $\mathrm{m}$. The uplands are dissected by five major tributaries of the Savannah River and their many feeder streams. The modern and Pleistocene floodplain terraces parallel the Savannah River, with elevations of 30-80 m. Soils in the terraces mostly are poorly to moderately well-drained soils ranging from clayey to sandy, depending on the local history of fluvial deposition.
The land that comprises the SRS was approximately $67 \%$ forested and $33 \%$ crop or pasture land at the time the property was acquired in 1950, and most of the accessible forested land had been logged (Workman and McLeod 1990). Today, industrial areas and radiological buffers areas comprise about $19 \%$ of the total area of the SRS. Another $20 \%$ is covered by wetlands, streams and impoundments (Davis and Janecek 1997). The remainder of the site is forested: $31 \%$ is hardwood or mixed hardwood and pine, $69 \%$ is planted with loblolly and longleaf pines. Nine percent of the forested and wetland areas is set aside in 30 separate tracts for environmental research.

\section{CAROLINA BAYS AND OTHER ISOLATED WETLAND PONDS}

About 400 Carolina bays and other small, isolated depression wetland ponds of differing origins occur on the SRS (Schalles et al. 1989, Kirkman et al. 1996). Thousands more occur throughout the Atlantic Coastal Plain of the southeastern United States. Those that are 


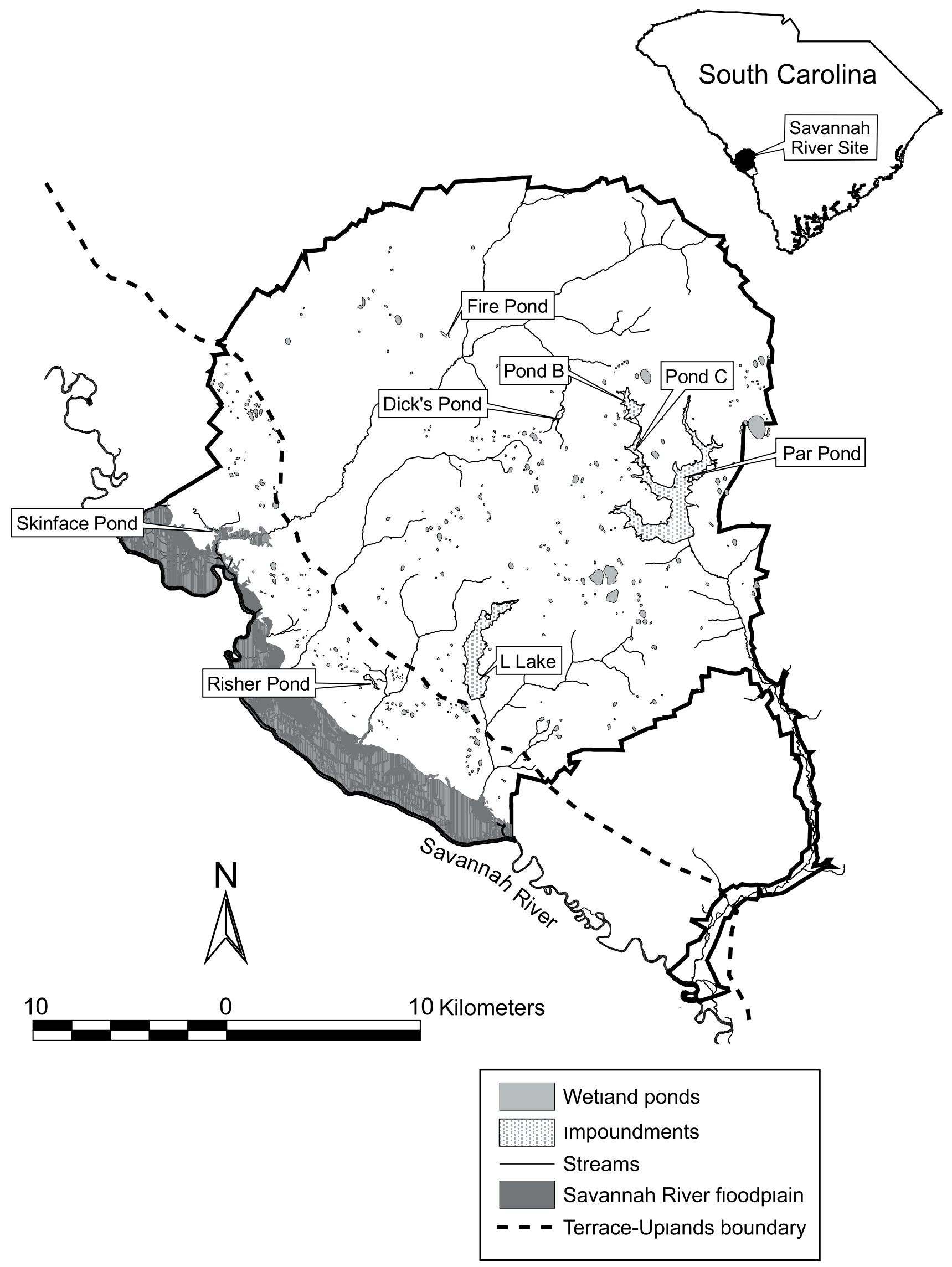


elliptical in shape, with a northwest-southeast orientation of their long axis, and are referred to as "Carolina bays" (see Bennett and Nelson 1991, Richardson and Gibbons 1993, Taylor et al. 1999). The wetland ponds in our studies were 0.4 to 50.2 ha in area, but most were under 2 ha. The largest, Bay 77 (Craig Pond), is also the largest Carolina bay on the SRS.

Duration and depth of filling vary among the wetland ponds, and among years within a pond (Schalles 1979, Lide et al. 1995, Medland and Taylor 2001). Most tend to fill in winter and dry in late spring or summer. The hydrologic cycle of most of these ponds is dominated by precipitation and evapotranspiration, while the importance of ground water inputs and outputs depends upon the depth of the water table (Lide et al. 1995). The waters tend to be acidic, soft, and moderately to heavily colored, with low levels of calcium and other solutes (Newman and Schalles 1990). Our studies found that the ponds were acidic to circumneutral $(\mathrm{pH}$ 4.3-6.4) with little seasonal variation.

Vegetation in basins of the wetland ponds ranges from forests to wetland meadows to open water (Bennett and Nelson 1991, Kirkman and Sharitz 1993, Kirkman et al. 1996, Schalles et al. 1989, Sharitz and Gresham 1997). Trees of forested ponds include black gum (Nyssa sylvatica), red maple (Acer rubrum), sweetgum (Liquidambar styraciflua), loblolly pine (Pinus taeda), and pond cypress (Taxodium ascendens). Shallow herbaceous ponds are typically dominated by emergent species including grasses (Panicum, Leersia) and bulrush (Scirpus cyperinus). Deeper areas may be dominated by floating species, such as water lily (Nymphaea odorata) and water shield (Brasenia schreberi). Many basins support a mixture of trees, herbaceous plants, and shrubs such as buttonbush (Cephalanthus occidentalis) and hollies (Ilex spp.).

Most of these wetland ponds lack fish. Some of the ponds that hold water on a more permanent basis do have resident fish populations (Frey 1951, Bailey and Frey 1958), and some of the less permanent ponds occasionally are invaded by fish during times of flooding (Bennett and McFarlane 1983, Snodgrass et al. 1996). The dominant vertebrates in most ponds are amphibians, which use the ponds for breeding (Bennett et al. 1979, Sharitz and Gibbons 1982). Larval salamanders are significant predators of microcrustaceans (Taylor et al. 1988).

Human activity has occurred in and around Carolina bays and other isolated ponds for at least 11,000 years (Eberhard et al. 1994). Most of the SRS ponds had been ditched and drained or regulated for agriculture and land development some time prior to 1950 (see Taylor et al. 1999). After the SRS was closed to public access in 1952, many of the wetland ponds were then left essentially undisturbed. The drainage ditches in many of these ponds have begun to fill in naturally, and many of them no longer function effectively.

\section{IMPOUNDMENTS}

Many farm and mill ponds in South Carolina were constructed during the $18^{\text {th }}$ and $19^{\text {th }}$ centuries (Kovacik and Winberry 1987); on what is now part of the SRS they were constructed in the late $18^{\text {th }}$ century (Brooks and Crass 1991). The earthen dams are susceptible to washout and only about a dozen still exist. The small impoundments included in this report were constructed between 1943 and 1951 (dates determined from aerial photographs), probably for farm or recreational use.

Four large reservoirs and several associated smaller impoundments were constructed to receive heated effluent from nuclear production reactors on the SRS (see DeBiase and Taylor 1993). The largest reservoir, Par Pond, was filled during 1958, as was the adjacent Pond C. These two reservoirs, along with Pond B (filled in 1961), are located on Lower Three Runs Creek and its tributary, Joyce Branch. The fourth impoundment, L Lake, is part of Steel Creek and was filled in 1985. No effluent was pumped into Pond B after 1964, while the remaining three received heated water until 1988.

The four small impoundments ranged from 0.6-2.2 ha, while the large reservoirs were 67-1012 ha in area. The $\mathrm{pH}$ at L Lake and Par Pond was circumneutral, ranging from 6.7-7.7. Pond $\mathrm{C}$ was slightly basic, ranging from 7.2-8.0, while Pond B was slightly acidic ( $\mathrm{pH}$ 6.0-6.9). The four small impoundments were slightly acid to circumneutral, with $\mathrm{pH}$ ranging from 5.0-7.0, but usually within 6.0-6.8. 


\section{COLLECTING AND IDENTIFYING MICROCRUSTACEANS}

\section{FIELD COLLECTIONS}

Microcrustaceans living in impoundments and lakes can be sampled with a variety of devices. Qualitative samples are most easily collected using a simple conical plankton net with 70-100 $\mu \mathrm{m}$ mesh. Plankton nets are useful in both open waters and in the vegetated areas of the littoral zone. Nets with larger openings $(30 \mathrm{~cm}$ or more diameter) are more efficient at collecting in open water, while nets with smaller openings $(20 \mathrm{~cm}$ diameter, sometimes called "student nets" by suppliers), are more easily maneuvered through vegetation.

Shallow wetland ponds present the microcrustacean collector with special sampling challenges. Very shallow water and dense vegetation often make it difficult to sample microcrustaceans with conventional methods, such as plankton nets. Aquarium hand nets are a useful tool in these situations. They can be modified by removing the netting and replacing it with a comparable net made of Nitex ${ }^{\circledR}$ bolting cloth. A mesh diameter of $100 \mu \mathrm{m}$ will efficiently collect virtually all microcrustacean species. Late-stage juvenile and adult clam shrimps and fairy shrimps are more efficiently collected with aquarium nets with the original netting in place. A finer mesh (\#100 $\mu \mathrm{m})$ is needed for collecting early juvenile stages of small species.

Microcrustaceans can be sampled quantitatively using a traditional quantitative water sampling device, such as a Van Dorn bottle, or by using a bucket or other container with a calibrated volume. The water sample can be passed through Nitex mesh to concentrate the sample (Taylor and Mahoney 1990). Vegetation-associated invertebrates may also be sampled using a bag sampler, as described in Leeper and Taylor (1998). Here, the whole water column, including plants is collected using a plastic bag mounted on a rigid frame.

Because microcrustacean species assemblages can change rapidly over time, a one-time sampling of a water body provides only a snapshot of the species present. A bi-monthly sampling schedule over a period of a year or more should allow for collection of nearly all species present at the sampling site. It should be noted that drought or above average rainfall can affect the numbers of species collected from temporary ponds, as such conditions influence the hatching of resting eggs.

\section{PRESERVATION AND STORAGE}

Microcrustaceans are routinely fixed and preserved with $70-95 \%$ ethanol or 3-5\% formaldehyde. Abrupt addition of the preservative may cause body distortions, or loss of eggs and embryos from the brood chambers of cladocerans. Narcotization with carbonated water (seltzer, club soda, bits of dry ice added to the water gradually until movement ceases) before preservation may reduce distortion and egg loss. The addition of sucrose to formaldehyde (600 mg sucrose per L of $37 \%$ formaldehyde, Haney and Hall 1973) will also prevent distortions of the specimens

Ethanol is generally the preferred preservative because it yields more relaxed specimens than those preserved in formaldehyde, and because it is far less toxic. It is the required preservative if any DNA work will be performed on the specimens. Formaldehyde will degrade DNA. However, larger volumes of ethanol are needed, making it more cumbersome for field use. It is also highly flammable and is a controlled substance. The stain rose bengal, used for making microcrustaceans and other arthropods more visible in debris-filled samples, is soluble in ethanol and will leach out of stained specimens during long-term storage. Dumont and Negrea (2002) also note that alcohols dissolve chitin over time and therefore recommend that they not be used for permanent storage.

Glass jars with Teflon-lined Bakelite ${ }^{\circledR}$ lids are the preferred storage containers. Specimens preserved in ethanol can be transferred into a combination of $70 \%$ ethanol and $1 \%$ glycerine for long-term storage. Because ethanol evaporates over time, specimens should be checked on a regular basis. The addition of the glycerine will help prevent specimens from drying out in the event that the ethanol does evaporate. Although formaldehyde does not evaporate so readily as ethanol, samples stored in formaldehyde should also be checked periodically. The addition of a small amount of glycerine is also beneficial to formaldehyde-preserved samples. Not only is it a precautionary measure against drying, but it also keeps the animals flexible. 


\section{IDENTIFICATION NOTES}

Specimens should be removed from their preservatives and rinsed thoroughly with water before identification proceeds. A stereomicroscope is adequate for identifying most microcrustaceans at least to order and often to genus. Dissection and observation under the higher magnification of a compound microscope are generally necessary for species identifications. Individual animals can be dissected in a drop of glycerine on a microscope slide or in water using a depression microscope slide. Dissections can be made using minuten pins mounted on sections of thin wooden dowel rods or in entomological pin vices. The cover slip may require support to prevent crushing of thick, larger specimens. Supports can be made from bits of broken cover slips or thin cardboard. Small amounts of modeling clay placed at the corners of the cover slip may also be used. Water and glycerine mounts are not permanent.

Numerous mounting media and techniques are available for making permanent mounts of microcrustaceans, with choices depending on the types of microscopy used. For ordinary light microscopy, permanent mounts can easily be made with one of two commercial mounting media, CMC-9 ${ }^{\circledR}$ (low viscosity) or CMC-10 ${ }^{\circledR}$ (high viscosity). Specimens can be transferred directly from water, formalin, ethanol, or lactic acid into the CMC medium. The specimen can be dissected in the medium, which also has clearing properties. Unless Nomarski (Differential Interference Contrast) microscopy is used, staining with $1 \%$ Chlorozole Black E, 1\% Eosin B, or 1\% Rose Bengal is recommended. Mounts made with $\mathrm{CMC}$ can be sealed with $\mathrm{CMC}$, although clear fingernail polish is also an excellent and less-expensive sealant. More detailed information on dissections and slide preparations can be found in Steedman (1976), Huys and Boxshall (1991), Koomen and Von Vaupel Klein (1995), Reid (2000), Dussart and Defaye (2001), and Dumont and Negrea (2002).

\section{TAXONOMIC REFERENCES}

The taxonomy and systematics of the North American Branchiopoda and Copepoda are constantly evolving. While some of the traditional general references on freshwater invertebrate identifications, such as Brooks (1959), Dexter (1959), Mattox (1959), Wilson (1959), Yeatman (1959), and Pennak (1989) are useful for identifying branchiopods and copepods, they do not include recent systematic updates or the numerous newly-described species. Hudson et al. (1998) note that at least 70 new species of free-living copepods have been described from North America since the publication of the keys by Wilson (1959) and Yeatman (1959).

Probably the most current general taxonomic keys for identification to genus level are those constructed by Dodson and Frey (1991) for the Branchiopoda and by Williamson (1991) for the Copepoda. The Dodson and Frey key is especially useful for identifying the difficult Chydoridae and Macrothricidae to genus. The older references are still useful for species-level identifications. For the North American calanoid copepods, Wilson (1959) is still the most appropriate key available, despite the description of at least six new Diaptomidae since its publication. More recent taxonomic revisions are available for many of the microcrustacean families. These are referenced in Appendix A, along with numerous publications describing individual species.

\section{MICROCRUSTACEAN SPECIES OF THE SAVANNAH RIVER SITE}

The species reported here were identified during several studies. Mahoney et al. (1990) conducted a survey of 23 wetland ponds during 1987. DeBiase and Taylor (2003) also detail the sampling efforts of three additional studies that contributed to the species reports presented here. The first, a survey of 88 Carolina bays and other wetland ponds, and 8 impoundments was conducted during 1990. The remaining two studies are long-term Carolina bay restoration projects. Bay 93 was sampled between 1994 and 2001. A separate project involving twenty Carolina bays began in 1998 and continued through 2004. Studies by Leeper and Taylor (1995) and Berner (1982) also contributed to the species list.

One hundred and fifteen microcrustacean species were identified on the SRS (Appendix A), including 71 cladoceran species, 15 calanoid copepod species, 25 cyclopoid species, two clam shrimp species, and 
two fairy shrimp species. Of these, 12 species are undescribed or are part of a species complex that is not fully defined taxonomically (Appendix B). Sixty-one of the microcrustacean species occurred only in wetland ponds, 15 species occurred only in impoundments, and 39 species occurred in both types of water bodies.

\section{BRANCHIOPODA: LARGE BRANCHIOPODA}

The anostracan Streptocephalus seali was collected in 27 ponds, while Eubranchipus moorei occurred only in two. The clam shrimps Limnadia lenticularis (Spinicaudata: Limnadiidae) and Lynceus gracilicornis (Laevicaudata: Lynceidae) were collected from 2 and 19 ponds respectively. None of these species occurred in the permanent impoundments. Both L. lenticularis populations co-occurred with $L$. gracilicornis and $S$. seali. Further details of large branchiopod occurrences on the SRS and elsewhere in South Carolina can be found in DeBiase and Taylor (2003).

The Notostraca do not occur on the Savannah River Site.

\section{BRANCHIOPODA: CLADOCERA}

Sixty species of cladocerans were collected from the wetland ponds and 39 species from the impoundments. Thirty-nine species occurred in both types of ponds. The most prevalent cladoceran families were the Daphniidae and the Chydoridae.

Bosminidae (3 species): Bosminopsis dietersi was restricted to impoundments. Bosmina longirostris, although ubiquitous, is rare in wetland ponds. Berner (1982) noted that Bosmina (Neobosmina) tubicen, a very common species in both wetland ponds and impoundments, is often difficult to distinguish from $B$. bagmanni, and listed the latter species in her key to the Cladocera of Par Pond (Berner 1982) as a species that may potentially occur there. We have not found $B$. bagmanni on the SRS.

Chydoridae (33 species): Two chydorid species were observed only in impoundments, while 18 were collected onlyin wetland ponds. Six of the species collected only from wetland ponds, (Acroperus sp., Chydorus brevilabris, Disparalona cf. acutirostris, Eurycercus vernalis, Paralona pigra, and Picripleuroxus denticulatus) were reported in Par Pond by Berner (1982). Berner (1982) also reports four Alona species (A. globulosa, A. kaura, A. setulosa, and A. verrucosa) from Par Pond that have not been observed during subsequent surveys on the SRS. Four additional chydorid species were reported from unpublished collections by David Frey and Diane Mahoney: Anchistropus minor, Chydorus bicollaris, Drepanothrix dentata, and Monospilus dispar.

DaphniIdae (14 Species): Among the cladocerans, this family showed more specialization by pond type. Only 5 species occurred in both wetland ponds and impoundments. Among them, Ceriodaphnia lacustris was observed only in one wetland pond, Bay 62 , which is adjacent to Par Pond. Two other species, C. cf. quadrangula and Ceriodaphnia sp., were reported as rarely occurring in Par Pond (Berner 1982), but not observed during the 1990 survey. Daphnia laevis occurred in wetland ponds, but not in permanent impoundments, while $D$. ambigua and $D$. parvula were found only in impoundments, with the latter occurring only in the large impoundments. Simocephalus vetulus was also restricted to impoundments.

Holopedidae (1 species): Holopedium cf. gibberum was found only in the impoundments. Berner (1982) notes that this species shows characteristics of both $H$. gibberum and its only congener, $H$. amazonicum, which is prevalent in the southeastern United States. She suggests that the SRS populations may be a transitional form of $H$. gibberum, based on work by Hegyi (1973). Korovchinsky (1992) notes that some populations have morphological peculiarities. Recent allozyme analyses by Hebert and Finston (1997) further confirm the wide range of morphological variability in this group, although they also suggest the possibility of additional species in this genus.

ILYoCRYPTIDaE (2 SPEcies): The family Ilyocryptidae was recently split from the Macrothricidae (Smirnov 1992). One species, Ilyocryptus spinifer, is relatively common on the SRS. A second species, I. bernerae, was described from Craig Pond (Kotov et al. 2002), but has not been observed in other ponds.

Leptodoridae (0 SPecies): Members of this family are absent from the SRS. However, Leptodora kindti has been collected in Hartwell, Russell, and Thurmond (Clarks Hill) Reservoirs on the Savannah River on the 
Georgia-South Carolina border (Wilde, 1998).

Macrothricidae (8 species): Four species appear to be restricted to the wetland ponds, although Macrothrix laticornis was recorded by Berner (1982) in Par Pond. Two additional macrothricid species, Leydigia cf. acanthocercoides and $L$. leydigii were collected from ponds in Jasper County, South Carolina (Taylor and DeBiase, unpubl. data). Two species, M. paulensis and M. superaculeata, occur in tropical Central and South America, but their range also reaches into the southern United States.

Moinidae (3 species): Although we collected Moina micrura in only one wetland pond (Bay 3-Flamingo Bay), it had been observed previously in two of the large impoundments (Par Pond and Pond C), which were receiving heated effluent at the time (Berner 1982, Taylor and Mahoney 1988, Leeper and Taylor 1995). Moina minuta was also reported in Pond C (Leeper and Taylor, 1995). The remaining species, Moinodaphnia macleay $i$, is fairly common in wetland ponds holding water in summer. This species is distributed world-wide throughout the tropics, as well as the southern United States (Goulden 1968).

Polyphemidae (1species): Polyphemus pediculus was restricted to wetland ponds. It is rare on the SRS, having been collected only from Bays 77 and 78 (Craig Pond and Sarracenia Bay).

SIDIDAE (7 SPECIES): Sida crystallina americana occurred strictly in large impoundments, while Pseudosida bidentata and Sarsilatona serricauda were found only in wetland ponds. Sarsilatona, a predominately Central and South American species, also occurs in the southern United States. On the SRS, it is present in the wetland ponds during the summer months. Latonopsis occidentalis was found only in Skinface Pond during the 1990 survey, however, it was reported in Par Pond by Berner (1982) and we observed it in Pond 4 (Taylor and DeBiase, unpubl. data), a small impoundment in the Par Pond system.

\section{COPEPODA: CALANOIDA}

Fifteen calanoid copepod species were observed on the SRS.
Centropagidae (1 species): Osphranticum labronectum was collected from wetland ponds and small impoundments. While most calanoid copepods are pelagic in habit, 0 . labronectum is more cyclopoidlike. It occurs predominately in the benthic and littoral zones.

Diaptomidae (12 species): The most common wetland diaptomid species were Onychodiaptomus sanguineus, Aglaodiaptomus atomicus, and Leptodiaptomus moorei. Three species, Onychodiaptomus birgei, Skistodiaptomus pallidus, and 0 . labronectum occurred both in temporary and permanent habitats. Skistodiaptomus mississippiensis and S. reighardi were found only in the impoundments on the SRS, however, both species have been collected from wetland ponds elsewhere. We found $S$. reighardi in collections made from ponds in North Carolina (DeBiase and Taylor 2000), and we collected S. mississippiensis from a wetland pond in Jasper County, South Carolina (DeBiase and Taylor, unpubl. data). Analysis of mitochondrial DNA for $S$. mississippiensis suggests that the taxon may include more than one species on the SRS (Staton et al. 2003). Skistodiaptomus floridanus was collected only from Bay 93. It was reported from Bay 120 by Mahoney et al. (1990), but not observed there during the 1990 survey.

Two diaptomid species have been observed elsewhere in South Carolina but not on the SRS. Aglaodiaptomus marshianus was collected from Coastal Plain ponds in Colleton and Jasper Counties, South Carolina (Taylor and DeBiase, unpubl. data). A congener, A. savagei, was described from a Carolina bay in Kershaw County (DeBiase and Taylor 2000). Its distribution extends into the coastal plain of North Carolina.

Temoridae (2 species): Epischura fluviatilis and Eurytemora affinis were restricted to the large impoundments. These species first appeared on the SRS in the 1980s (DeBiase and Taylor 1993).

\section{COPEPODA: CYCLOPOIDA}

Cyclopidae (25 species): All cyclopoid species were observed in the wetland ponds, and eleven of these also occurred in the impoundments. Fourteen cyclopoid species were restricted to the wetland ponds, including all of the Diacyclops except $D$. crassicaudis brachycercus 
(Appendix A). Three species, Acanthocyclops robustusvernalis, Mesocyclops edax, and Tropocyclops prasinus mexicanus, were collected from all water body types, however, M. edax was observed in only one wetland pond. The remainder of the species were collected from the wetland ponds and small impoundments; they are likely also present in the large impoundments.

\section{ECOLOGICAL ASSOCIATIONS}

Basin type and hydroperiod duration are the most important influences on species richness and composition of microcrustacean assemblages. The types of vegetation in the basin have a moderate influence on species richness. Unless recently established or severely degraded, wetland ponds with moderate to long hydroperiods and impoundments often support 20 or more species of microcrustaceans (Fig. 11). Ponds with shorter hydroperiods often support 10 or fewer species. Forested ponds support fewer species (mean 16 species/ pond) than those with herbaceous (mean 22 species/ pond) or mixed (mean 18 species/pond) vegetation. Wetland ponds on the terraces of the Savannah River support more species (mean 22 species/pond) than those in the upland (mean 16 species/pond). especially among the Diacyclops, are also strongly associated with the wetland ponds.

The cladocerans Daphnia ambigua and Holopedium gibberum, the calanoid copepod Skistodiaptomus mississippiensis, and the cyclopoid copepod Mesocyclops edax occur characteristically in the open water, planktonic habitats. In contrast to their counterparts in wetland ponds, these species are small (except for $\mathrm{H}$. gibberum) and nearly transparent, traits that may reduce the intensity of predation by fish. The gelatinous envelope surrounding $H$. gibberum may provide additional protection.
Many microcrustacean species can occur across a broad range of hydrologic conditions (Fig. 12). The stresses of filling and drying in wetland ponds do not exclude many species. Only a dozen of the species found in the SRS impoundments have not been found in the wetland ponds. However, the proportion of wetland pond specialists is greater in ponds with shorter hydroperiods.

A dozen or so species are strongly characteristic for wetland ponds on the SRS. The cladoceran Daphnia laevis and brightly colored calanoid copepods, including the Aglaodiaptomus species, are common. Fairy shrimps and clam shrimps are fairly common and very conspicuous in wetland ponds with short hydroperiods. Cyclopoid copepods are less conspicuous, but some species,

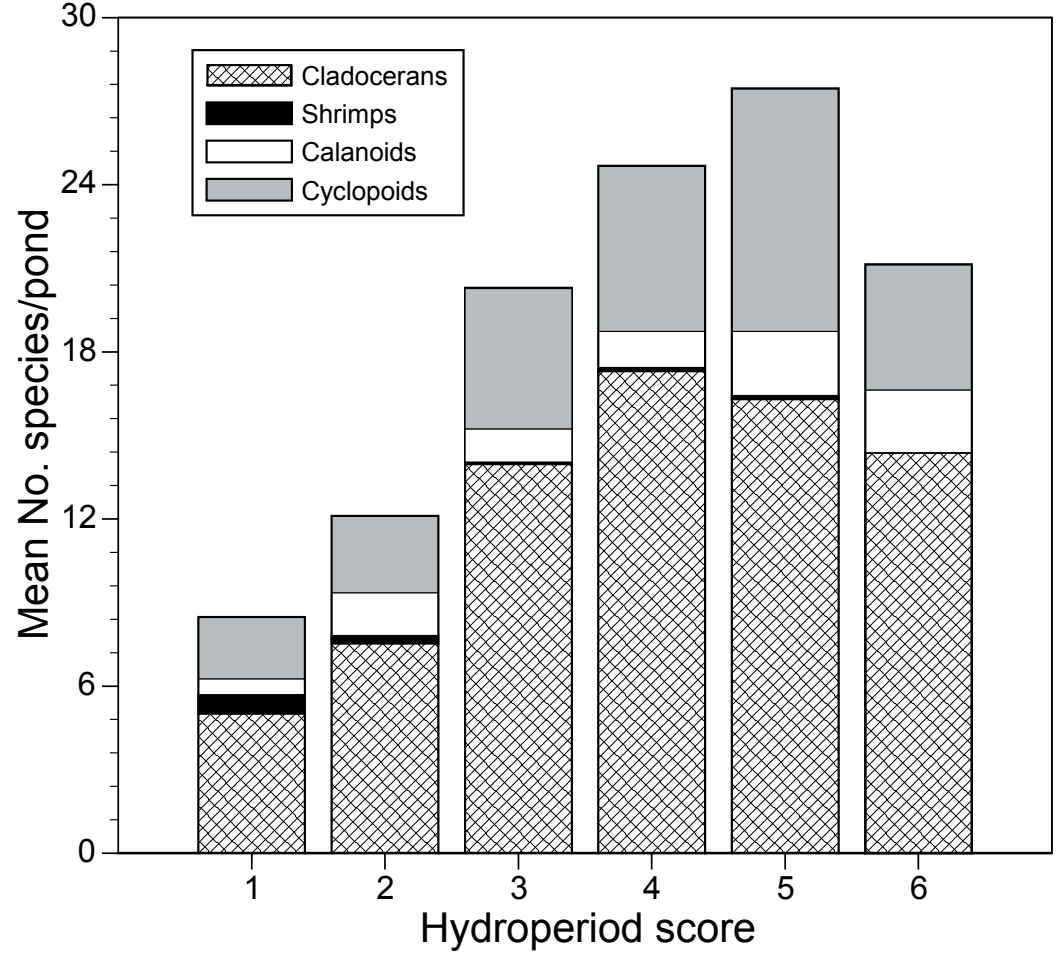

Figure 11. Species richness (mean no. of species \pm s.e.) response to bydrologic class. 
Bosminopsis dietersi Bosmina longirostris Eubosmina tubicen

Alona hamulata

Chydorus gibbus Alona costata

Alona quadrangularis Chydorus piger

Eurycercus microdontus

Eurycercus vernalis

Alona rustica

Alonella excisa

Chydorus sp. 3

Pseudochydorus globosus Alona affinis Alona guttata

Chydorus biovatus

Chydorus sp. 1

Oxyurella brevicaudis Acroperus sp.

Chydorus brevilabris

Dunhevidia americana

Pleuroxus straminius Kurzia latissima

Pleuroxus denticulatus Alonella exigua

Alonella pulchella

Camptocercus sp.

Disparalona acutirostris

Ephemeroporus hybridus

Ephemeroporus sp. 2

Ephemeroporus sp. 1

Alona intermedia

Daphnia ambigua

Daphnia parvula

Simocephalus vetulus

Ceriodaphnia lacustris

Ceriodaphnia cf. cornuta

Ceriodaphnia cf. dubia

Ceriodaphnia sp.

Simocephalus exspinosus

Simocephalus serrulatus

Scapholeberis armata armata

Ceriodaphnia laticaudata

Ceriodaphnia megops Daphnia laevis

Ceriodaphnia cf. quadrangula

Holopedium gibberum

Macrothrix cf. superaculeata

Ilyocryptis spinifer

Macrothrix sp. 2

Macrothrix laticornis

Acantholeberis curvirostris

Grimaldina brazzai Lathonura sp.

Strebelocercus serricaudatus

Moina micrura

Moinodaphnia macleayi

Polyphemus pediculus

Latona setifera

Diaphanosoma birgei

Diaphanosoma brachyurum

Sida crystallina

Pseudosida bidentata

Limnadia lenticularis

Lynceus gracilicornis

Streptocephalus seali

Wt. mean

- Wt. mean, $\mathrm{n}<5$ ponds

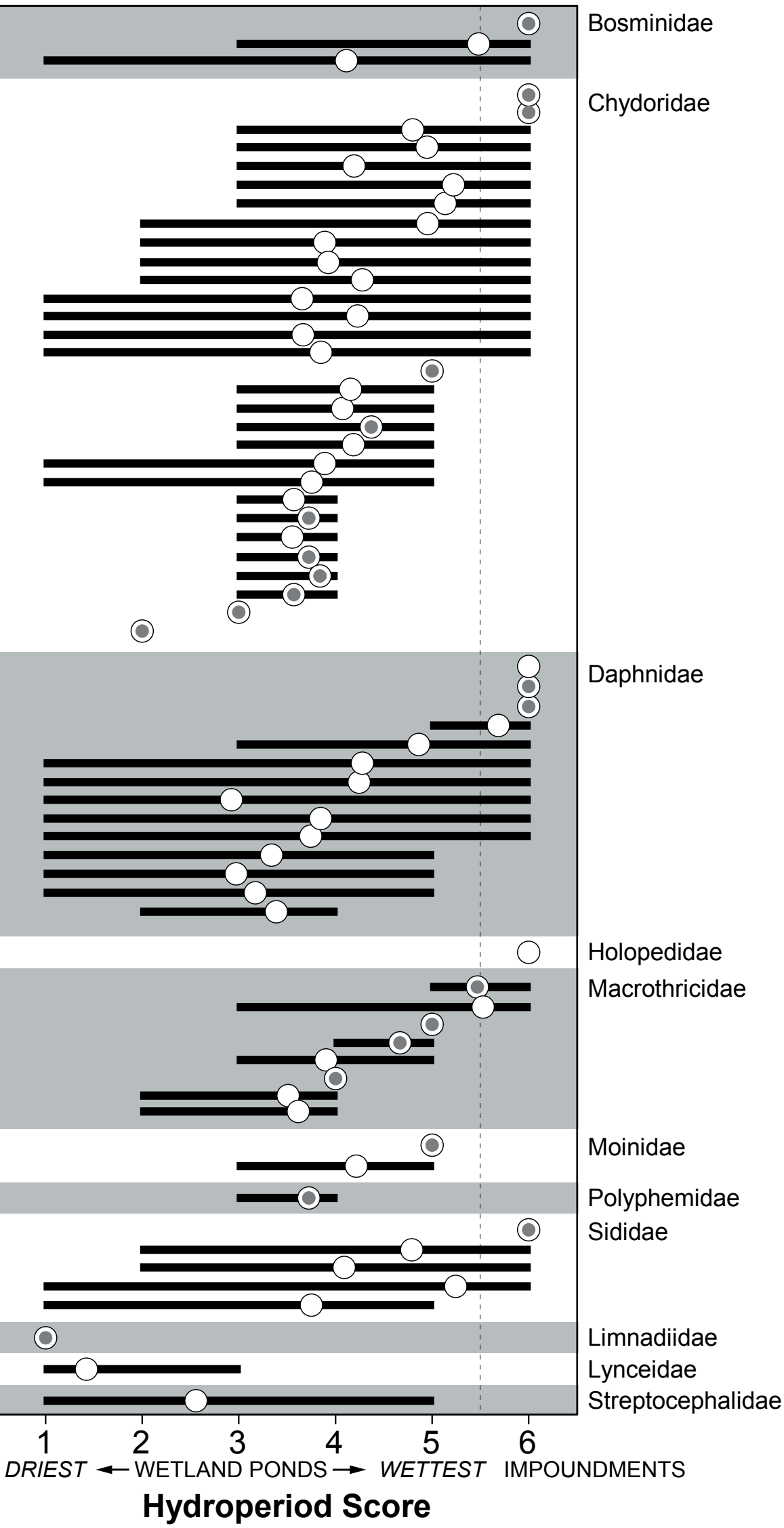

Figure 12. Hydrologic ranges of common branchiopod and copepod species on the SRS. Data based on 1990 Carolina bay survey. "Hydroperiod score" represents the number of visits during which the ponds held water. The sites were sampled six times during the year. Permanently-flooded bodies (i.e., impoundments) received a score of 6. 


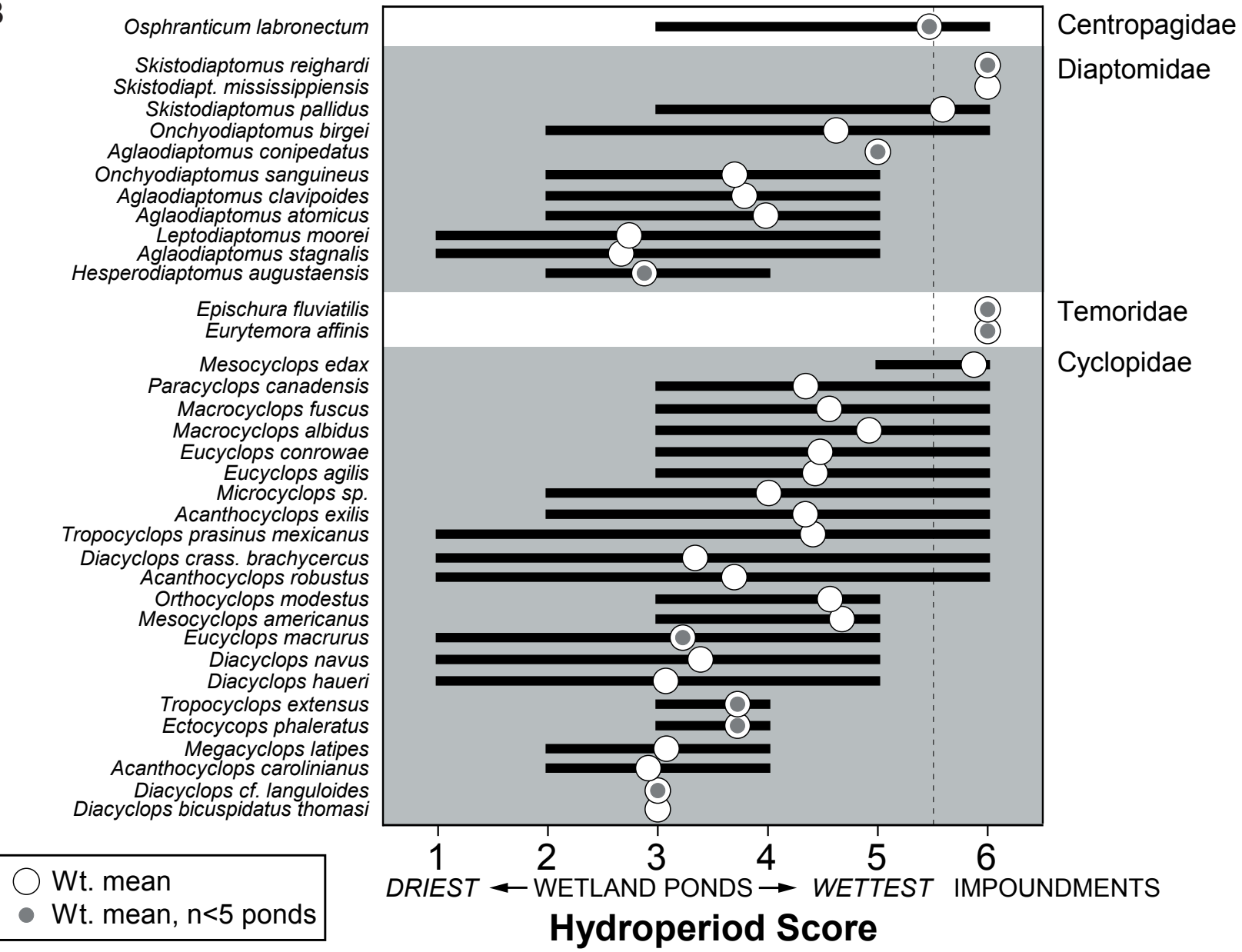

Figure 12. Hydrologic ranges of common branchiopod and copepod species on the SRS. Data based on 1990 Carolina bay survey. "Hydroperiod score" represents the number of visits during which the ponds held water. The sites were sampled six times during the year. Permanently-flooded bodies (i.e., impoundments) received a score of 6.

\section{FINAL COMMENTS: WHY IDENTIFY?}

At just over a hundred species, branchiopods and calanoid and cyclopoid copepods on the Savannah River Site present a substantial, but accessible richness of species. Identifications in most families are fairly easy for the patient novice. Chydorid and macrothricid cladocerans and cyclopoid copepods may be the most problematic, due to the number of incompletely resolved species. Undescribed species could be encountered in any family.

Descriptions of assemblages are useful in evaluating the ecological health of pond communities. The demonstrated association between species richness and hydroperiod offers possibilities for developing biotic indices for the condition of a wetland using microcrustaceans. Because microcrustaceans must rely on passive transport by wind, water, or larger animals to colonize new habitats, their composition may recover more slowly from long-term disturbance than that of aquatic insects. However, their abilities to persist in resting stages require caution in interpreting absence from surveys of limited scope.

Conservation status of microcrustaceans is poorly known for the Southeast, but two species of calanoid copepods from southeastern wetland ponds are ranked "vulnerable" by the World Conservation Union (IUCN). Both species occur in South Carolina. We have collected Hesperodiaptomus augustaensis in four ponds on the SRS. We have collected Aglaodiaptomus marshianus in wetland ponds on the Lower Coastal Plain. 
For the impoundments, monitoring for invasion by exotic speciesmaybethemostimportantconsideration. Therange of the copepod Eurytemora affinis, a largely marine and brackish water species, apparently expanded into the SRS in the 1980's (DeBiase and Taylor 1993). The range of the other SRS temorid copepod, Epischura fluviatilis, may also have expanded into this region (DeBiase and Taylor 1993). Its range is still poorly known, and copepods had been largely ignored on the SRS previous to our studies. Three exotic cladoceran species have invaded the Great Lakes, as well as other lakes throughout North America. None of these species, Daphnia lumboltzi, Cercopagis pengoi, and Bythotrephes cedarstroemi (Fig. 13), has yet been detected on the SRS, although $D$. lumboltzi has been collected from several locations elsewhere in South Carolina (Fox and Vahjen 1999). Bythotrephes and Cercopagis are predatory and have substantial potential to disrupt planktonic food webs, as was observed in Great Lakes (Lehman and Cacères 1993). Furthermore, both species have barbed caudal (tail) spines, which snag onto fishing lines and downrigger cables, causing fouling. Daphnia lumboltzi is non-predatory, but it has the potential to replace native Daphnia species. This species is a very recent invader. Consequently, it is too soon to see the effects of its invasion.
A

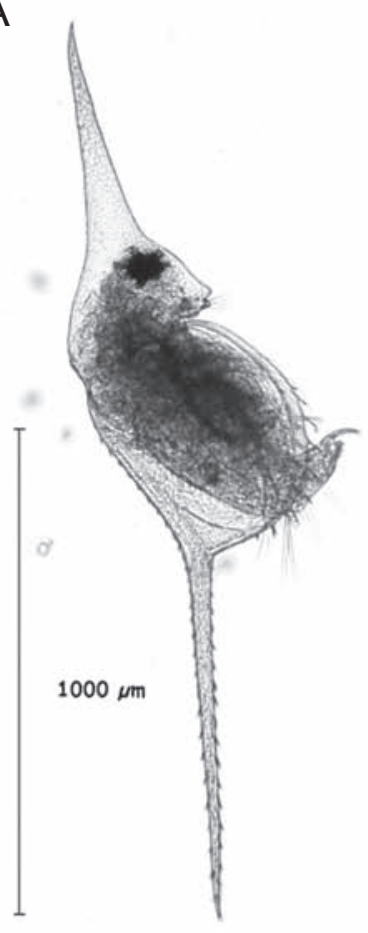

B

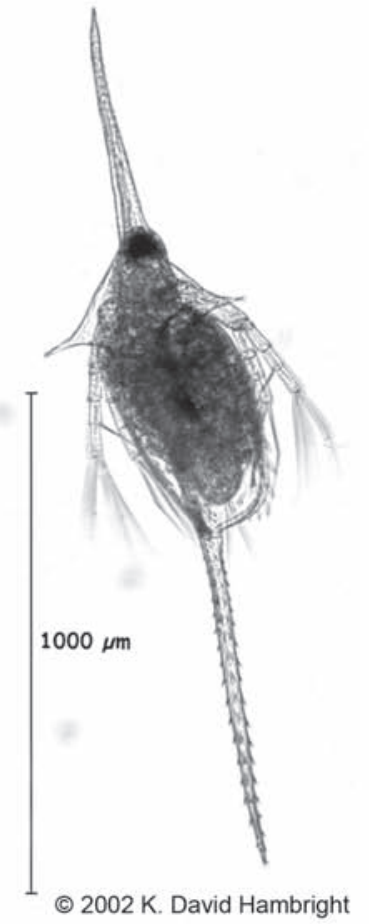

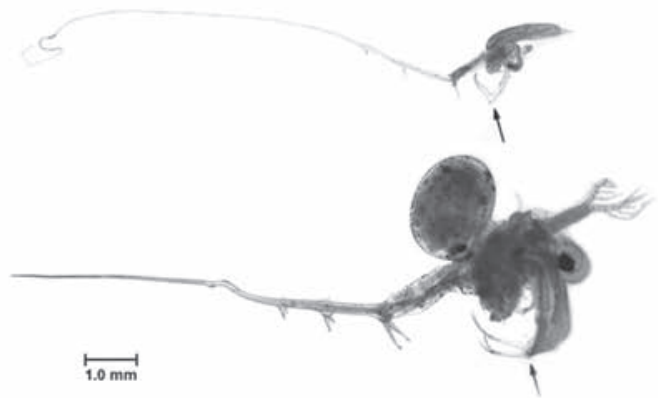

Figure 13. [A] Lateral and ventral views of Daphnia lumholtzi. Photomicrograph taken by David Hambright, 2003;

[B] Cercopagis pengoi (upper) and Bythotrephes cederstroemii. Photomicrograph taken by Hank Vanderploeg, GLERL, 2001, photo \# 1017.

\section{ACKNOWLEDGMENTS}

Diane Mahoney contributed extensively to the design of the 1990 survey. We thank her, Douglas Leeper, Susan Dietz-Brantley, and numerous others for field assistance. Taxonomic assistance from Dorothy L. Berner, Brenda Hann, Janet W. Reid, Clay Sassaman, and the late Thomas E. Bowman and David G. Frey is greatly appreciated. Winona Specht and I. Lehr Brisbin reviewed a previous draft of this document and made suggestions that improved the final product. This report was supported by the Environmental Remediation Sciences Division of the Office of Biological and Environmental Research of the U.S. Department of Energy, through the Financial Assistance Award No. DEFC09-96SR18546 to the University of Georgia Research Foundation. 


\section{REFERENCES}

Anderson, D.T. 1967. Larval development and segment formation in the branchiopod crustaceans Limnadia stanelyana and Artemia salina (L.) (Anostraca). Australian Journal of Zoology 15:47-91.

Bailey, J.R. and D.G. Frey. 1958. Darters of the genus Hololepis from some natural lakes of North Carolina. Journal of the Elisha Mitchell Scientific Society 67:191-203.

Bayly, I.A.E. 1992. The non-marine Centropagidae. Guides to the identification of the microinvertebrates of the continental waters of the World. Vol. 2. H.J.F. Dumont (coord. ed.). SPB Academic Publ. Amsterdam, The Netherlands. 30 pp.

Belk, D. 1975. Key to the Anostraca (fairy shrimps) of North America. Southwestern Naturalist 20:91-103.

Bennett, D.H. and R.W. McFarlane. 1983. The Fishes of the Savannah River Plant: National Environmental Research Park. National Environmental Research Park Publications, U.S. Department of Energy and Savannah River Ecology Laboratory, Aiken, SC. NERPSRO-12. $152 \mathrm{pp}$.

Bennett, S.H., J.W. Gibbons and J. Glanville. 1979. Terrestrial activity, abundance and diversity of amphibians in differently managed forest types. American Midland Naturalist 103:412-416.

Bennett, S.H. and J.B. Nelson. 1991. Distribution and status of Carolina bays in South Carolina. Nongame and Heritage Trust Section, South Carolina Wildlife and Marine Resource Department. No. 1.88 pp.

Berner, D.B. 1982. Key to the Cladocera of Par Pond on the Savannah River Plant. U.S. Department of Energy Savannah River Plant National Environmental Research Park. NERP-SRO-11. 62 pp.

Berner, D.B. 1985. Morphological differentiation among species in the Ceriodaphnia cornuta complex (Crustacea, Cladocera). Verhandlungen Internationale Vereinigung für Theoretische und Angewandte Limnologie 22:3099-3103.

Bernice, R. 1971. Food, feeding and digestion in Streptocephalus dichotomus Baird (Crustacea: Anostraca). Hydrobiologia 38:507-520.

Bohonak, A.J. and H.H. Whiteman. 1999. Dispersal of the fairy shrimp Branchinecta coloradensis (Anostraca): effects of hydroperiod and salamanders. Limnology and Oceanography 44:487-493.

Bowman, T.E. 1991. Epischura fluviatilis Herrick, 1883
(Copepoda: Calanoida: Temoridae), first report from South Carolina, with notes on sexual dimorphism in the caudal rami and its possible role in mating. Journal of Crustacean Biology 11:460-462.

Brooks, J.L. 1957. The systematics of North American Daphnia. Memoirs of the Connecticut Academy of Arts and Sciences 13. $180 \mathrm{pp}$.

Brooks, J.L. 1959. Cladocera. Pp. 587-656 In: W. T. Edmondson (ed.). Freshwater Biology. $2^{\text {nd }}$ ed. John Wiley and Sons, New York, NY, USA.

Brooks, R.D. and D.C. Crass. 1991. A desperate poor country: History and settlement patterning on the Savannah River Site, Aiken and Barnwell Counties, South Carolina. Savannah River Archaeological Research Papers 2. South Carolina Institute of Archaeology and Anthropology, University of South Carolina, Columbia. 108 pp.

Brtek, J. 1967. Eubranchipus (Creaseria) moorei N. sp. Annotationes Zoologicae et Botanicae 36:1-7, Tafel I-IV.

Brtek, J. and G. Mura. 2000. Revised key to families and genera of the Anostraca with notes on their geographical distribution. Crustaceana 73:1037-1088.

Burns, C.W. and J.J. Gilbert. 1986. Effects of daphniid size and density on interference between Daphnia and Keratella cochlearis. Limnology and Oceanography 31:848-858.

Daborn, G.R. 1976. The life cycle of Eubranchipus bundyi (Forbes) (Crustacea: Anostraca) in a temporary vernal pond of Alberta. Canadian Journal of Zoology 55:280-287.

D'Agostino, A. 1980. The vital requirements of Artemia; physiology and nutrition. Pp. 56-82 In: G. Persoone, P. Sorgeloos, 0. Roels, and E. Jaspers (eds.). The brine shrimp Artemia. Vol. 2: Physiology, biochemistry, molecular biology. Universa Press, Wetteren, Belgium.

Dahms, H.-U. and C.H. Fernando. 1994. Redescription of female Macrocyclops fuscus (Jurine, 1820) (Copepoda, Cyclopoida) from Ontario with a description of naupliar stages. Journal of Plankton Research 16:9-21.

Davis C.E. and L.L. Janecek. 1997. DOE research set-aside areas of the Savannah River Site. Savannah River Site National Research Park Program Publication No. SRO-NERP-25. 229 pp. 
DeBiase, A.E. and B.E. Taylor. 1993. New occurrences of Eurytemora affinis and Epischura fluviatilis, freshwater calanoid copepod species of the family Temoridae, in South Carolina. American Midland Naturalist 130:386-392.

DeBiase, A.E. and B.E. Taylor. 1997. Aglaodiaptomus atomicus, a new species (Crustacea: Copepoda: Calanoida: Diaptomidae) from freshwater wetland ponds in South Carolina, U.S.A., and a redescription of A. saskatchewanensis. Proceedings of the Biological Society of Washington 110:569-580.

DeBiase, A.E. and B.E. Taylor. 2000. A new calanoid copepod species from South Carolina, U.S.A.: Aglaodiaptomus savagei (Crustacea: Copepoda: Calanoida: Diaptomidae). Proceedings of the Biological Society of Washington 113:681-689.

DeBiase, A.E. and B.E. Taylor. 2003. New reports of fairy shrimps (Crustacea: Anostraca) and clam shrimps (Crustacea: Laevicaudata and Spinicaudata) from South Carolina. Southeastern Naturalist 2:207-216.

Deevey, E.S., Jr. and G.B. Deevey. 1971. The American species of Eubosmina Seligo (Crustacea, Cladocera). Limnology and Oceanography 16:201-218.

DeMelo, R. and P.D.N. Hebert. 1994. A taxonomic reevaluation of North American Bosminideae. Canadian Journal of Zoology 72:1808-1825.

Dexter, R.W. 1959. Anostraca. Pp. 558-571 In: W.T. Edmondson (ed.). Freshwater Biology, 2nd ed. John Wiley and Sons, New York, NY, USA.

Dodson, S.I. and D.G. Frey. 1991. Cladoceran and other Branchiopoda. Pp. 723-786 In: Thorp, J.H. and A.P. Covich (eds.). Ecology and classification of North American freshwater invertebrates. Academic Press, San Diego, CA, USA.

Dodson, S.I., A.K. Grishanin, K. Gross and G.A. Wyngaard. 2003. Morphological analysis of some cryptic species of the Acanthocyclops vernalis species complex from North America. Hydrobiologia 500:131-143.

Dumont, H.J. and S.V. Negrea. 2002. Introduction to the Class Branchiopoda. Guides to the identification of the microinvertebrates of the continental waters of the World. Vol. 19. Coord. Ed. H.J.F. Dumont. SPB Academic Publ. Amsterdam, The Netherlands. 398 pp.

Dumont, H.J. and J. Pensaert. 1983. A revision of the Scapholeberinae (Crustacea: Cladocera). Hydrobiologia 100:3-45.

Dussart, B.H. 1985. Le genre Mesocyclops. (Crustacé,
Copépode) en Amérique du Nord. Canadian Journal of Zoology 63:961-964.

Dussart, B.H. and D. Defaye. 2001. Introduction to the Copepoda ( $2^{\text {nd }}$ Edition). Guides to the identification of the microinvertebrates of the continental waters of the World. Vol. 16. H.J.F. Dumont (coord. ed.). SPB Academic Publ. Amsterdam, The Netherlands. $344 \mathrm{pp}$.

Dussart, B.H. and C.H. Fernando. 1990. A review of the taxonomy of five Ontario genera of freshwater cyclopoid Copepoda (Crustacea). Canadian Journal of Zoology 68: 2594-2604.

Eberhard, K., K.E. Sassaman and M.J. Brooks. 1994. Crosby Bay (38AK682): Paleoindian and Early Archaic occupations at a Carolina bay in Aiken County, South Carolina. South Carolina Antiquities 26:33-46.

Edmondson, W.T. and A.H. Litt. 1987. Conochilus in Lake Washington. Hydrobiologia 147:157-162.

Einsle, U. 1996. Copepoda: Cyclopoida. Genera Cyclops, Megacyclops, Acanthocyclops. Guides to the identification of the microinvertebrates of the continental waters of the World. Vol. 10. H.J.F. Dumont (coord. ed.). SPB Academic Publ., Langenargen, Germany. 83 pp.

Elgmork, K. 1967. Ecological aspects of diapause in copepods. Pp. 647-954 In: Proceedings of the Symposium on Crustacea, Series 2, Part III, Ernakulam, Marine Biological Association of India.

Elgmork, K., 1986. Evolutionary aspects of diapause in freshwater copepods. Pp. 411-418 In: W.C. Kerfoot (ed.). Evolution and ecology of zooplankton communities. University Press of New England, Hanover, New Hampshire.

Elgmork, K. and J.P. Nilssen. 1978. Equivalence of copepod and insect diapause. Verhandlungen Internationale Vereinigung für Theoretische und Angewandte Limnologie 20:2518-2523.

Fox, R.S. and M. Vahjen. 1999. The colonization of South Carolina reservoirs by the exotic cladoceran, Daphnia lumboltzi. Bulletin of the South Carolina Academy of Science 1999:89

Frey, D.G. 1951. The fishes of North Carolina's bay lakes and their intraspecific variation. Journal of the Elisha Mitchell Scientific Society 67:1-44.

Frey, D.G. 1965. Differentiation of Alona costata Sars from two related species (Cladocera, Chydoridae). Crustaceana 8:159-173.

Frey, D.G. 1978. A new species of Eurycercus (Cladocera, 
Chydoridae) from the southern United States. Tulane Studies in Zoology and Botany 20:1-25.

Frey, D.G. 1980. On the plurality of Chydorus sphaericus (0. F. Müller) (Cladocera, Chydoridae), and designation of a neotype from Sjales $\varnothing$, Denmark. Hydrobiologia 69:83-123.

Frey, D.G. 1982a. The reticulated species of Chydorus (Cladocera, Chydoridae): two new species with suggestions of convergence. Hydrobiologia 93:255271.

Frey, D.G. 1982b. Relocation of Chydorus barroisi and related species (Cladocera, Chydoridae) to a new genus and description of two new species. Hydrobiologia 86:231-269.

Frey, D.G. 1985. A new species of the Chydorus sphaericus group (Cladocera, Chydoridae) from western Montana. Internationale Revue der gesamten Hydrobiologie 70:3-20.

Frey, D.G. 1987. The taxonomy and biogeography of the Cladocera. Hydrobiologia 145:5-17.

Frey, D.G. 1988. Separation of Pleuroxus laevis Sars, 1861 from two resembling species in North America: Pleuroxus straminius Birge, 1879 and Pleuroxus chiangi n.sp. (Cladocera, Chydoridae). Canadian Journal of Zoology 66:2534-2563.

Frey, D.G. 1993. Subdivision of the genus Pleuroxus (Anomopoda, Chydroridae) into subgenera worldwide. Hydrobiologia 262:133-144.

Fryer, G. 1957. The food of some freshwater cyclopoid copepods and its ecological significance. Journal of Animal Ecology 25:263-286.

Fryer, G. 1968. Evolution and adaptive radiation in the Chydoridae (Crustacea: Cladocera): a study in comparative functional morphology and ecology. Philosophical Transactions of the Royal Society of London, Series B, Biological Sciences 254:221-385.

Fryer, G. 1983. Functional ontogenetic changes in Brachinecta ferox (Milne-Edwards) (Crustacea: Anostraca). Philosophical Transactions of the Royal Society of London, Series B. 303:229-343.

Goulden, C.E. 1968. The systematics and evolution of the Moinidae. Transactions of the American Philosophical Society 58:1-101.

Haney, J.F. and D.J. Hall. 1973. Sugar-coated Daphnia: a preservation technique for Cladocera. Limnology and Oceanography 18:331-333.

Hann, B.J. 1982. Two new species of Eurycercus (Bullatifrons) from eastern North America
(Chydoridae, Cladocera). Taxonomy, ontogeny and biology. Internationale Revue der gesamten Hydrobiologie 67:585-610.

Hann, B.J. and R. Chengalath. 1981. Redescription of Alonella pulchella Herrick, 1884 (Cladocera, Chydoridae), and a description of the male. Crustaceana 41:249-262.

Hebert, P.D.N. 1995. The Daphnia of North AmericaAn Illustrated Fauna. CD-ROM Ver. 1. University of Guelph.

Hebert, P.D.N. and T.L. Finston. 1997. Taxon diversity of the genus Holopedium (Crustacea: Cladocera) from the lakes of eastern North America. Canadian Journal of Fisheries and Aquatic Sciences 54:1928-1936.

Hegyi, M.A. 1973. Aspects of the ecology, distribution and systematics of the genus Holopedium (Cladocera, Crustacea). Ph.D. thesis, University of Tennessee, Knoxville.

Hudson, P.L., J.W. Reid, L.T. Lesko and J.H. Selgeby. 1998. Cyclopoid and harpacticoid copepods of the Laurentian Great Lakes. Ohio Biological Survey Bulletin NS12 (2). 50 pp.

Hutchinson, G.E. 1967. A treatise on Limnology. Volume II. Introduction to lake biology and the limnoplankton. John Wiley and Sons, Inc. New York, NY, USA. 1115 pp.

Huys, R. and G. Boxshall. 1991. Copepod evolution. The Ray Society, London. 468 pp.

Jack, J.D. and J.J. Gilbert. 1994. Effects of Daphnia on microzooplankton communities. Journal of Plankton Research 16:1499-1512.

Kaestner, A. 1970. Invertebrate Zoology. Volume 3: Crustacea (English Edition). Wiley (Interscience), New York, NY, USA.

Karyatug, S. 1999. Copepoda: Cyclopoida. Genera Paracyclops, Ochridacyclops and key to the Eucyclopinae. Guides to the identification of the microinvertebrates of the continental waters of the World. Vol. 14. H.J.F. Dumont (coord. ed.). Backhuys Publ., Leiden, The Netherlands. 217 pp.

Kerfoot, W.C. 1980. Perspectives on cyclomorphosis: separation of phenotypes and genotypes. Pp. 470496 In: W.C. Kerfoot (ed.). Evolution and ecology of zooplankton communities. Special Symposium Vol. 3. American Society of Limnology and Oceanography. University of New England Press, Hanover, New Hampshire, USA.

Kirkman, L.K. and R.R. Sharitz. 1993. Growth in controlled 
water regimes of three grasses common in freshwater wetlands of the southeastern USA. Aquatic Botany 44:345-359.

Kirkman, L.K, R.F. Lide, G. Wein and R.R. Sharitz. 1996. Vegetation changes and land-use legacies of depression wetlands of the western coastal plain of South Carolina: 1951-1992. Wetlands 15:564-576.

Koomen, P. and J.C. Von Vaupel Klein. 1995. The suitability of various mounting media for permanent mounts of small chitinous crustaceans, with special reference to the observation of integumental organs. Crustaceana 68:428-437.

Koøínek, V. 1981. Diaphanosoma birgei n. sp. (Crustacea, Cladocera). A new species from America and its widely distributed sub species Diaphanosoma birgei ssp. lacustris n. ssp. Canadian Journal Zoology 59:1115-1121.

Korovchinsky, N.M. 1992. Sididae and Holopediidae (Crustacea: Daphniiformes). SPB Academic Publishing, The Hague, The Netherlands. 82 pp.

Korovchinsky, N.M. 2002. Description of two new species of Diaphanosoma Fischer, 1850 (Crustacea, Branchiopoda, Sididae) from the United States and Canada and species richness of the genus in North America. Hydrobiologia 489:45-54.

Kotov, A.A., M. Elías-Gutiérrez and J.L. Williams. 2002. A preliminary revision of sordidus-like species of Ilyocryptus Sars, 1862 (Anomopoda, Branchiopoda) in North America, with description of I. bernerae n. sp. Hydrobiologia 472:141-176.

Kotov, A.A. and J.L. Williams. 2000. Ilyocryptus spinifer Herrick 1882 (Anomopoda, Branchipoda): a redescription based on North American material and designation of a neotype from Minnesota. Hydrobiologia 428:67-84.

Kovacik, C.F. and J.J. Winberry. 1987. South Carolina: The making of a landscape. University of South Carolina Press, Columbia, SC, USA. 235 pp.

Lampert, W. 1987. Feeding and nutrition in Daphnia. Pp. 143-192 In: R.H. Peters and R. deBernardi (eds.). "Daphnia." Memorie dell'Instituto Italiano di Idrobiologia Volume 45.

Lee, C.E. 1999. Rapid and repeated invasions of fresh water by the copepod Eurytemora affinis. Evolution 53:1423-1434.

Leeper, D.A. and B.E. Taylor. 1995. Plankton composition, abundance and dynamics in a severely stressed cooling reservoir. Journal of Plankton Research
17:821-843.

Leeper, D.A. and B.E. Taylor. 1998. Abundance, biomass and production of aquatic invertebrates in Rainbow Bay, a temporary wetland in South Carolina, USA. Archiv für Hydrobiologie 143:335-362.

Lehman, J.T. 1987. Palearctic predator invades North American Great Lakes. Oecologia 74:478-480.

Lehman, J.T. and C.E. Cacères. 1993. Food-web responses to species invasion by a predatory invertebrate: Bythotrephes in Lake Michigan. Limnology and Oceanography 38:879-891.

Lide, R.F., V.G. Meentenmeyer, J.E. Pinder, III and L.M. Beatty. 1995. Hydrology of a Carolina bay located on the upper coastal plain of western South Carolina. Wetlands 15:47-57.

Mahoney, D.L., M.A. Mort and B.E. Taylor. 1990. Species richness of calanoid copepods, cladocerans, and other branchiopods in Carolina bay temporary ponds. American Midland Naturalist 123:244-258.

Martin, J.W., B.E. Flegenhauer and L.G. Abele. 1986. Redescription of the clam shrimp Lynceus gracilicornis (Packard) (Branchiopoda, Conchostraca, Lynceidae) from Florida, with notes on its biology. Zoologica Scripta 15:221-232.

Mattox, N.T. 1959. Conchostraca. Pp. 577-586 In: W.T. Edmondson (ed.). Freshwater Biology, 2nd ed. John Wiley and Sons, New York, NY, USA.

Medland, V.L. and B.E. Taylor. 2001. Strategies of emergence from diapause for cyclopoid copepods in a temporary pond. Archiv für Hydrobiologie 150:329-349.

Michael, R.G. and D.G. Frey. 1983. Assumed amphiAtlantic distribution of Oxyurella tenuicaudis (Cladocera, Chydoridae) denied by a new species from North America. Hydrobiologia 106:3-35.

Monakov, A.V. 1972. Review of studies on feeding of aquatic invertebrates conducted at the Institute of Biology of Inland Waters, Academy of Science, USSR. Journal of the Fisheries Research Board of Canada 29:363-383.

Newman, M.C. and J.F. Schalles. 1990. The water chemistry of Carolina bays: A regional survey. Archives of Environmental Contamination and Toxicology. 118:147-168.

Orlova-Bienkowskaja, M.Y. 2001. Cladocera: Anomopoda. Daphniidae: genus Simocephalus. Guides to the identification of the microinvertebrates of the continental waters of the World. Vol. 17. 
H.J.F. Dumont (coord. ed.). SPB Academic Publ. Amsterdam, The Netherlands. $130 \mathrm{pp}$.

Pennak, R.W. 1989. Fresh-water invertebrates of the United States. Wiley \& Sons, Inc., New York, NY, USA. $628 \mathrm{pp}$.

Porter, K.G. 1973. Selective grazing and differential digestion of algae by zooplankton. Nature (London) 2444:179-180.

Porter, K.G. 1977. The plant-interface in freshwater ecosystems. American Scientist 65:159-170.

Porter, K.G., Y.S. Feig and E.F. Vetter. 1983. Morphology, flow regimes, and filtering rates of Daphnia, Ceriodaphnia, and Bosmina fed natural bacteria. Oecologia 58:156-163.

Rajapaska, R. and C.H. Fernando. 1987. Redescription of Dunbevedia serrata Daday. 1898 (Cladocera, Chydoridae) and a description of Dunhevedia americana sp. nov. from America. Canadian Journal of Zoology 65:432-440.

Reid, J.W. 1988. Copepoda (Crustacea) from a seasonally flooded marsh in Rock Creek Stream Valley Park, Maryland. Proceedings of the Biological Society of Washington 101:31-38.

Reid,J.W. 1989.Diacyclops navus (Crustacea:Copepoda) redescribed from Louisiana, U.S.A., Transactions of the American Microscopical Society 108:332-344.

Reid,J.W. 1991. Some species of Tropocyclops (Crustacea, Copepoda) from Brazil, with a key to the American species. Bijdragen to de Dierkunde 61:3-15.

Reid,J.W. 1992a. Redescription of Diacyclops nearcticus (Kiefer, 1934) and description of four similar new congeners from North America, with comments on $D$. crassicaudis (G.O. Sars, 1863) and D. crassicaudis var. brachycercus (Kiefer, 1927). (Crustacea: Copepoda). Canadian Journal of Zoology 70:14451469.

Reid,J.W. 1992b. Copepoda (Crustacea) from fresh waters of the Florida Everglades, U.S.A., with a description of Eucyclops conrowae n. sp. Transactions of the American Microscopical Society 111:229-254.

Reid, J.W. 2000. Workshop on taxonomic techniques for copepods. Smithsonian Institution, National Museum of Natural History, Washington DC. http://nmnhwww. si.edu/iz/copepod/techniques.htm.

Reid, J.W. and L.D. Moreno. 1999. The western and southern distribution of Mesocyclops edax (S.A. Forbes) (Crustacea: Copepoda: Cyclopoida). Proceedings of the Biological Society of Washington
112:581-591.

Richardson, C.J. and J.W. Gibbons. 1993. Pocosins, Carolina bays, and mountain bogs. Pp. 257-310 In: W.H. Martin, S.G. Boyce, and A.C. Echternacht (eds.). Biodiversity of the Southeastern United States. Lowland terrestrial communities. John Wiley and Sons, New York, NY, USA.

Roff, J.C. 1972. Aspects of the reproductive biology of the planktonic copepod Limnocalanus macrurus Sars, 1863. Crustaceana 22:155-160.

Schalles, J.F. 1979. Comparative limnology and ecosystem analysis of Carolina bay ponds on the Upper Coastal Plain of South Carolina. Ph.D. Dissertation, Emory University, Atlanta, GA, USA.

Schalles, J.F., R.R. Sharitz, J.W. Gibbons, G.J. Leversee and J.N. Knox. 1989. Carolina bays of the Savannah River Plant. National Environmental Research Park Report. Savannah River Ecology Laboratory, University of Georgia Press, Athens, GA, USA. 70 pp.

Sharitz, R.R. and J.W. Gibbons. 1982. The ecology of evergreen shrub bogs, pocosins and Carolina bays of the Southeast: a community profile. U.S. Fish Wildlife Service, Division of Biological Services, Washington D.C. FWS/0BS-82/04. 93 pp.

Sharitz, R.R. and C.A. Gresham. 1997. The ecology of southeastern shrub bogs (pocosins) and Carolina bays. Pp. 343-377 In: Messina, M.G., and W.H. Conner (eds.). Southern Forested Wetlands: Ecology and Management. CRC/Lewis Publishers, Boca Raton, FL, USA.

Smirnov, N.N. 1971. Chydoridae fauny mira. Fauna SSR. Nov. Ser. No. 101. Rakoobraznyye. Volume 1. vyp. 2. (Available in English from Israel Program for the Scientific Translations, Jerusalem, 1974).

Smirnov, N.N. 1992. The Macrothricidae of the World. SPB Academic Publishing, The Hague, The Netherlands. $143 \mathrm{pp}$.

Smirnov, N.N. 1996. Cladocera: The Chydorinae and Sayciinae (Chydoridae) of the World. SPB Academic Publishing, The Hague, The Netherlands. 197 pp.

Smith, K.E. and C.H. Fernando. 1977. New records and little known freshwater copepods (Crustacea, Copepoda) from Ontario. Canadian Journal of Zoology. 55: 1874-1884.

Snodgrass, J.W., A.L. Bryan, Jr., R.F. Lide and G.M. Smith. 1996. Factors affecting fish assemblages in isolated wetlands of the Upper Coastal Plain, U.S.A. Canadian Journal of Fisheries and Aquatic Sciences. 53:443- 
454.

Staton, J.L., B.E. Taylor, N.V. Schizas, R. Wetzler, T.C. Glenn and B. C. Coull. 2003. Mitochondrial gene diversity of Skistodiaptomus mississippiensis in impoundments of the Upper Coastal Plain near Aiken, South Carolina, USA. Archiv für Hydrobiologie 158:215-231.

Steedman, H.F. 1976. Zooplankton fixation and preservation. UNESCO Press, Paris. 350 pp.

Taylor, B.E. and D.L. Mahoney. 1988. Extinction and recolonization: Processes regulating zooplankton dynamics in a cooling reservoir. Verhandlungen Internationale Vereinigung für Theoretische und Angewandte Limnologie 23:2536-1541.

Taylor, B.E. and D.L. Mahoney. 1990. Zooplankton in Rainbow Bay, a Carolina bay pond: population dynamics in a temporary habitat. Freshwater Biology 24:597-612.

Taylor, B.E., R.A. Estes, J.H.K. Pechmann and R.D. Semlitsch. 1988. Trophic relations in a temporary pond: larval salamanders and their microinvertebrate prey. Canadian Journal of Zoology 66:2191-2198.

Taylor, B.E., G.A. Wyngaard and D.L. Mahoney. 1990. Hatching of Diaptomus stagnalis eggs from a temporary pond after a prolonged dry period. Archiv für Hydrobiolgie 117:271-278.

Taylor, B.E., D.A. Leeper, M.A. McClure and A.E. DeBiase. 1999. Carolina bays: Ecology of aquatic invertebrates and perspectives on conservation. Pp.167-196 In: Batzer, D.P., R.B. Rader and S.A. Wissinger (eds.). Invertebrates in Freshwater Wetlands of North America: Ecology and Management. John Wiley and Sons, New York, NY, USA.

Thiéry, A. 1996. Branchiopodes: I. Ordres des Anosteracés, Notostacés, Spinicaudata et Laevicaudata. In: P.P. Grassé and J. Forest (eds.). Traité de Zoologie, Masson, Paris, 7 Crustacés 2:287-351.

Turner, C.H. 1910. Ecological notes on the Cladocera and Copepoda of Augusta, Georgia, with descriptions of new or little known species. Transactions of the Academy of Sciences of St. Louis 19:151-176.

Ueda, H. andJ.W. Reid (eds). 2003. Copepoda: Cyclopoida. Genera Mesocyclops and Thermocyclops. Guides to the identification of the microinvertebrates of the continental waters of the World. Vol. 20. Coord. ed. H.J.F. Dumont. Backhuys Publ., Leiden, The Netherlands. 318 pp.

Vanderploeg, H.A. and G.-A. Paffenhöfer. 1985. Modes of algal capture by the freshwater copepod Diaptomus sicilis and their relation to food-size selection. Limnology and Oceanography 30:871-885.

Wickham, S.A. and J.J. Gilbert. 1991. Relative vulnerabilities of natural rotifer and ciliate communities to cladocerans: laboratory and field experiments. Freshwater Biology 26:77-86.

Wike, L.D., R.W. Shipley, J.A. Bowers, A.L. Bryan, C.L. Cummins, B.R. del Carmen, G.P. Friday, J.E. Irwin, H.E. Mackey, Jr., J.J. Mayer, E.A. Nelson, M.H. Paller, V.A. Rogers, W.L. Specht and E.W. Wilde. 1994. SRS Ecology. Environmental Information Document. WSRC-TR-93-496. Westinghouse Savannah River Company, Aiken, SC, USA.

Wilde, S.B. 1998. Advective regulation of zooplankton assemblages in a reservoir series on the Savannah River, SC/GA. Ph.D. Dissertation. University of Georgia, Athens, GA, USA. 137 pp.

Williams, D.D. 1987. The ecology of temporary waters. Croom Helm Publ., London, England. 205 pp.

Williams-Howze, J. 1997. Dormancy in the free-living copepod orders Cyclopoida, Calanoida, and Harpacticoida. Oceanography and Marine Biology: An Annual Review Vol. 35, pp. 257-321.

Williamson, C.E. 1983. Invertebrate predation on planktonic rotifers. Hydrobiologia 104:385-396.

Williamson, C.E. 1986. Predation on rotifers by the suspension-feeding calanoid copepod Diaptomus pallidus. Limnology and Oceanography 3:393-402.

Williamson, C.E. 1991. Copepoda. Pp. 787-822 In: Thorp, J.H., and A.P. Covich (eds.). Ecology and classification of North American freshwater invertebrates. Academic Press, San Diego.

Wilson, M.S. 1954. A new species of Diaptomus from Louisiana and Texas with notes on the subgenus Leptodiaptomus. Tulane Studies in Zoology 2:51-60.

Wilson, M.S. 1955. A new Louisiana copepod related to Diaptomus (Aglaodiaptomus) clavipes Schacht. Tulane Studies in Zoology 3:37-46.

Wilson, M.S. 1959. Calanoida. Pages 738-794 in W.T. Edmondson (ed.) Freshwater Biology. $2^{\text {nd }}$ ed. John Wiley and Sons, New York, NY, USA.

Workman, S.W. and K.W. McLeod. 1990. Vegetation of the Savannah River Site: major community types. Savannah River Site National Environmental Research Park Program. SRO-NERP-19. 137 pp.

Yeatman, H.C. 1944. American cyclopoid copepods of the viridis-vernalis group of Cyclopidae. Canadian 
Journal of Zoology 36:285-303.

Yeatman, H.C. 1959. Cyclopoida. Pages 795-815 In: W.T.

Edmondson (ed.). Freshwater Biology, 2nd ed. John

Wiley and Sons, New York, NY, USA. 


\section{APPENDIX A}

Branchiopod, cyclopoid, and calanoid copepod species from the Savannah River Site.

\begin{tabular}{|c|c|c|c|c|c|}
\hline Taxon & Synonymy & References & $\begin{array}{l}\text { Wetland } \\
\text { Ponds }\end{array}$ & $\begin{array}{l}\text { Impound- } \\
\text { ments }\end{array}$ & $\begin{array}{l}\text { Small } \\
\text { Impound- } \\
\text { ments }\end{array}$ \\
\hline \multicolumn{6}{|l|}{ BRANCHIOPODA } \\
\hline \multicolumn{6}{|l|}{ Anostraca } \\
\hline \multicolumn{6}{|l|}{ Chirocephalidae } \\
\hline $\begin{array}{l}\text { Eubranchipus moorei Brtek } \\
1967\end{array}$ & & $\begin{array}{l}\text { Brtek 1967; Belk 1975; Brtek } \\
\text { and Mura } 2000\end{array}$ & Yes & No & No \\
\hline \multicolumn{6}{|l|}{ Streptocephalidae } \\
\hline $\begin{array}{l}\text { Streptocephalus seali Ryder } \\
1879\end{array}$ & & Dexter 1959; Belk 1975 & Yes & No & No \\
\hline \multicolumn{6}{|l|}{ Laevicaudata } \\
\hline \multicolumn{6}{|l|}{ Lynceidae } \\
\hline $\begin{array}{l}\text { Lynceus gracilicornis Packard } \\
1871\end{array}$ & & $\begin{array}{c}\text { Mattox 1959; Martin et al. } \\
1986\end{array}$ & Yes & No & No \\
\hline \multicolumn{6}{|l|}{ Spinicaudata } \\
\hline \multicolumn{6}{|l|}{ Limnadiidae } \\
\hline $\begin{array}{l}\text { Limnadia lenticularis Linnaeus } \\
1761\end{array}$ & & Mattox 1959 & Yes & No & No \\
\hline \multicolumn{6}{|l|}{ Cladocerans } \\
\hline \multicolumn{6}{|l|}{ Bosminidae } \\
\hline $\begin{array}{l}\text { Bosmina longirostris 0.F. Müller } \\
1785\end{array}$ & & DeMelo and Hebert 1994 & Yes & Yes & Yes \\
\hline $\begin{array}{l}\text { Bosmina (Neobosmina) } \\
\text { tubicen (Brehm 1953) }\end{array}$ & $\begin{array}{c}\text { Eubosmina } \\
\text { tubicen (Deevey } \\
\text { and Deevey } \\
\text { 1971,Berner } \\
\text { 1982) }\end{array}$ & DeMelo and Hebert 1994 & Yes & Yes & Yes \\
\hline $\begin{array}{l}\text { Bosminopsis dietersi } \text { Richard } \\
1895\end{array}$ & & DeMelo and Hebert 1994 & No & Yes & No \\
\hline Chydoridae & & Dodson and Frey 1991 & & & \\
\hline Acroperus sp. & & $\begin{array}{l}\text { Frey collection; Brooks 1959; } \\
\text { Berner } 1982\end{array}$ & Yes & $\mathrm{No}^{\mathrm{a}}$ & No \\
\hline Alona affinis Baird 1843 & & Brooks 1959 & Yes & $\mathrm{No}^{\mathrm{a}}$ & Yes \\
\hline A. costata Sars 1862 & & $\begin{array}{l}\text { Frey collection; Brooks 1959; } \\
\text { Frey } 1965\end{array}$ & Yes & No & Yes \\
\hline Alona cf. diaphana & & Frey collection & Yes & No & No \\
\hline A. guttata Sars 1862 & & Frey collection; Brooks 1959 & Yes & Yes & Yes \\
\hline A. bamulata & & Brooks 1959 & No & Yes & No \\
\hline A. intermedia Sars 1862 & & Brooks 1959 & Yes & No & No \\
\hline
\end{tabular}




\begin{tabular}{|c|c|c|c|c|c|}
\hline Taxon & Synonymy & References & $\begin{array}{l}\text { Wetland } \\
\text { Ponds }\end{array}$ & $\begin{array}{l}\text { Impound- } \\
\text { ments }\end{array}$ & $\begin{array}{l}\text { Small } \\
\text { Impound- } \\
\text { ments }\end{array}$ \\
\hline $\begin{array}{l}\text { A. quadrangularis O.F. Müller } \\
1785\end{array}$ & & Brooks 1959 & Yes & Yes & No \\
\hline A. rustica Scott 1895 & & $\begin{array}{l}\text { Frey collection; Brooks 1959; } \\
\text { Frey 1965; Berner } 1982\end{array}$ & Yes & $\mathrm{No}^{\mathrm{a}}$ & Yes \\
\hline Alonella cf. excisa Fischer 1854 & & Brooks 1959; Smirnov 1996 & Yes & No & Yes \\
\hline A. exigua Lilljeborg 1853 & & Brooks 1959; Smirnov 1996 & Yes & No & No \\
\hline A. pulchella King 1853 & & $\begin{array}{l}\text { Frey collection; Brooks 1959; } \\
\text { Hann and Chengalath 1981; } \\
\text { Smirnov } 1996\end{array}$ & Yes & No & No \\
\hline Camptocercus sp. & & Frey collection; Brooks 1959 & Yes & No & No \\
\hline C. biovatus Frey 1985 & & Frey 1985; Smirnov 1996 & Yes & No & No \\
\hline C. brevilabris Frey 1980 & & Frey 1980; Smirnov 1996 & Yes & $\mathrm{No}^{\mathrm{a}, \mathrm{b}}$ & No \\
\hline C. linguilabris Frey 1982 & & Frey 1982a; Smirnov 1996 & Yes & No & No \\
\hline C. gibbus & & & No & Yes & No \\
\hline Chydorus sp. 1 & $\begin{array}{l}\text { Chydorus } \mathrm{cf} . \\
\text { sphaericus }\end{array}$ & Frey 1980 & Yes & Yes & Yes \\
\hline Chydorus sp. 2 & $\begin{array}{l}\text { Chydorus } \mathrm{cf} . \\
\text { sphaericus }\end{array}$ & Frey 1980 & Yes & Yes & Yes \\
\hline Paralona pigra Sars 1852 & Chydorus piger & Brooks 1959; Smirnov 1996 & Yes & $\mathrm{No}^{\mathrm{a}}$ & Yes \\
\hline $\begin{array}{l}\text { Disparalona cf. acutirostris } \\
\text { (Birge 1879) }\end{array}$ & & Brooks 1959; Smirnov 1996 & Yes & $\mathrm{No}^{\mathrm{a}}$ & No \\
\hline D. hamata (Birge 1879) & & $\begin{array}{l}\text { Frey collection; Smirnov } \\
1996\end{array}$ & Yes & No & No \\
\hline $\begin{array}{l}\text { Dunbevidia americana } \\
\text { Rajapaska and Fernando } 1987\end{array}$ & $\begin{array}{c}\text { Alonella } \\
\text { bamulata, } \\
\text { Pleuroxus } \\
\text { bamulatus } \\
\text { (Brooks 1959; } \\
\text { Pennak 1989) }\end{array}$ & $\begin{array}{l}\text { Brooks 1959; Berner 1982; } \\
\text { Smirnov } 1996\end{array}$ & Yes & $\mathrm{No}^{\mathrm{a}}$ & No \\
\hline $\begin{array}{l}\text { Ephemeroporus hybridus group } \\
\text { Daday } 1905\end{array}$ & & $\begin{array}{l}\text { Frey collection; Brooks 1959; } \\
\text { Smirnov } 1996\end{array}$ & Yes & Yes & No \\
\hline Ephemeroporus sp. 1 & & $\begin{array}{c}\text { Frey collection; Rajapaska } \\
\text { and Fernando 1987; Smirnov } \\
1996\end{array}$ & Yes & No & No \\
\hline $\begin{array}{l}\text { Ephemeroporus archboldi } \text { Frey } \\
1982\end{array}$ & $\begin{array}{l}\text { Ephemeroporus } \\
\text { sp. } 2\end{array}$ & Frey 1982b & Yes & Yes & No \\
\hline $\begin{array}{l}\text { Eurycercus microdontus Frey } \\
1978\end{array}$ & & Frey 1978 & Yes & Yes & Yes \\
\hline E. vernalis Hann 1982 & & Hann 1982 & Yes & $\mathrm{No}^{\mathrm{a}}$ & Yes \\
\hline Kurzia latissima Kurz 1874 & & Frey collection; Brooks 1959 & Yes & No & No \\
\hline $\begin{array}{l}\text { Oxyurella brevicaudis Michael } \\
\text { and Frey } 1983\end{array}$ & & Michael and Frey 1983 & Yes & No & No \\
\hline
\end{tabular}




\begin{tabular}{|c|c|c|c|c|c|}
\hline Taxon & Synonymy & References & $\begin{array}{l}\text { Wetland } \\
\text { Ponds }\end{array}$ & $\begin{array}{l}\text { Impound- } \\
\text { ments }\end{array}$ & $\begin{array}{l}\text { Small } \\
\text { Impound- } \\
\text { ments }\end{array}$ \\
\hline $\begin{array}{l}\text { Picripleuroxus denticulatus } \\
\text { (Birge 1879) }\end{array}$ & $\begin{array}{c}\text { Pleuroxus } \\
\text { denticulatus }\end{array}$ & $\begin{array}{l}\text { Frey collection; Brooks 1959; } \\
\text { Frey 1988, 1993; Smirnov } \\
1996\end{array}$ & Yes & $\mathrm{No}^{\mathrm{a}}$ & No \\
\hline P. straminius (Birge 1879) & $\begin{array}{l}\text { Pleuroxus } \\
\text { straminius }\end{array}$ & $\begin{array}{l}\text { Frey collection; Brooks 1959; } \\
\text { Frey 1988; Smirnov } 1996\end{array}$ & Yes & No & No \\
\hline $\begin{array}{l}\text { Pseudochydorus globosus (Baird } \\
1843 \text { ) }\end{array}$ & & $\begin{array}{l}\text { Frey collection; Brooks 1959; } \\
\text { Smirnov } 1996\end{array}$ & Yes & Yes & No \\
\hline \multicolumn{6}{|l|}{ Daphniidae } \\
\hline $\begin{array}{l}\text { Ceriodaphnia cf. cornuta Sars } \\
1885\end{array}$ & & $\begin{array}{l}\text { Berner 1982, 1985, pers. } \\
\text { comm. }\end{array}$ & Yes & Yes & No \\
\hline C. cf. dubia Richard 1894 & & Berner, pers. com. & Yes & No & No \\
\hline C. lacustris Birge 1893 & & $\begin{array}{l}\text { Brooks 1959; Berner, pers. } \\
\text { comm. }\end{array}$ & Yes $^{r}$ & Yes & Yes \\
\hline C. laticaudata P. E. Müller 1767 & & Berner, pers. com. & Yes & No & No \\
\hline C. megops Sars 1861 & & $\begin{array}{l}\text { Brooks 1959; Berner, pers. } \\
\text { com. }\end{array}$ & Yes & No & No \\
\hline $\begin{array}{l}\text { C. cf. quadrangula O.F. Müller } \\
1785\end{array}$ & & Berner, pers. com. & Yes & $\mathrm{No}^{\mathrm{a}}$ & No \\
\hline Ceriodaphnia sp. Dana 1853 & & Berner, pers. com. & Yes & & Yes \\
\hline $\begin{array}{l}\text { Daphnia ambigua Scourfield } \\
1947\end{array}$ & & $\begin{array}{c}\text { Brooks 1957, 1959; Hebert } \\
1995\end{array}$ & No** & & Yes \\
\hline D. laevis Birge 1879 & & $\begin{array}{c}\text { Brooks 1957, 1959; Hebert } \\
1995\end{array}$ & Yes & & No \\
\hline D. parvula Fordyce 1901 & & $\begin{array}{c}\text { Brooks } 1957,1959 ; \text { Hebert } \\
1995\end{array}$ & No** & & No \\
\hline $\begin{array}{l}\text { Scapholeberis armata armata } \\
\text { Herrick } 1887\end{array}$ & $\begin{array}{l}\text { Scapholeberis } \\
\text { kingi (Mahoney } \\
\text { et al. 1990) }\end{array}$ & Dumont and Pensaert 1983 & Yes & Yes & Yes \\
\hline $\begin{array}{l}\text { Simocephalus exspinosis DeGeer } \\
1778\end{array}$ & & $\begin{array}{l}\text { Brooks 1959; Orlova- } \\
\text { Bienkowskaja } 2001\end{array}$ & Yes & No & Yes \\
\hline S. serrulatus Koch 1841 & & Brooks 1959 & Yes & Yes & Yes \\
\hline S. vetulus Schlødler 1858 & & Brooks 1959 & No & Yes & Yes \\
\hline \multicolumn{6}{|l|}{ Holopedidae } \\
\hline $\begin{array}{l}\text { Holopedium cf. gibberum } \\
\text { Zaddach } 1885\end{array}$ & & $\begin{array}{l}\text { Brooks 1959; Berner 1982; } \\
\text { Korovchinsky } 1992\end{array}$ & No & Yes & Yes \\
\hline \multicolumn{6}{|l|}{ Ilyocryptidae } \\
\hline $\begin{array}{l}\text { Ilyocryptus bernerae Kotov et } \\
\text { al. } 2002\end{array}$ & & Kotov et al. 2002 & Yes & No & No \\
\hline $\begin{array}{l}\text { Ilyocryptus spinifer Herrick } \\
1884\end{array}$ & & $\begin{array}{l}\text { Brooks 1959; Smirnov 1992; } \\
\text { Kotov and Williams } 2000\end{array}$ & Yes & Yes & Yes \\
\hline Macrothricidae & & Dodson and Frey 1991 & & & \\
\hline
\end{tabular}




\begin{tabular}{|c|c|c|c|c|c|}
\hline Taxon & Synonymy & References & $\begin{array}{l}\text { Wetland } \\
\text { Ponds }\end{array}$ & $\begin{array}{l}\text { Impound- } \\
\text { ments }\end{array}$ & $\begin{array}{l}\text { Small } \\
\text { Impound- } \\
\text { ments }\end{array}$ \\
\hline $\begin{array}{l}\text { Acantholeberis curvirostris O.F. } \\
\text { Müller } 1785\end{array}$ & & Smirnov 1992 & Yes & No & No \\
\hline $\begin{array}{l}\text { Grimaldina brazzai } \text { Richard } \\
1892\end{array}$ & & Brooks 1959; Smirnov 1992 & Yes & No & No \\
\hline $\begin{array}{l}\text { Lathonura cf. rectirostris O.F. } \\
\text { Müller } 1785\end{array}$ & & Smirnov 1992 & Yes & No & No \\
\hline $\begin{array}{l}\text { Macrothrix laticornis Jurine } \\
1820\end{array}$ & & Smirnov 1992 & Yes & $\mathrm{No}^{\mathrm{a}}$ & No \\
\hline $\begin{array}{l}\text { M. cf. superaculeata Smirnov } \\
1982\end{array}$ & & Smirnov 1992 & Yes & No & Yes \\
\hline Macrothrix paulensis Sars 1862 & $\begin{array}{l}\text { Iheringula } \\
\text { paulensis }\end{array}$ & Smirnov 1992 & & & \\
\hline Macrothrix sp. & & & Yes & Yes & Yes \\
\hline $\begin{array}{l}\text { Strebelocercus serricaudatus } \\
\text { Fischer } 1849\end{array}$ & & Smirnov 1992 & Yes & Yes & Yes \\
\hline \multicolumn{6}{|l|}{ Moinidae } \\
\hline Moina micrura Kurz 1874 & & Brooks 1959; Goulden 1968 & Yes & Yes $^{\mathrm{b}}$ & No \\
\hline M. minuta Hansen 1899 & & Leeper and Taylor 1995 & No & Yes & No \\
\hline $\begin{array}{l}\text { Moinodaphnia macleayi King } \\
1853\end{array}$ & & Brooks 1959; Goulden 1968 & Yes & No & No \\
\hline \multicolumn{6}{|l|}{ Polyphemidae } \\
\hline $\begin{array}{l}\text { Polyphemus pediculus Linné } \\
1761\end{array}$ & & Brooks 1959 & Yes & No & No \\
\hline \multicolumn{6}{|l|}{ Sididae } \\
\hline $\begin{array}{l}\text { D. brachyurum sens. str. Liéven } \\
1848\end{array}$ & & Korovchinsky 1992 & Yes & Yes & Yes \\
\hline $\begin{array}{l}\text { Diaphanosoma } \mathrm{cf} \text {. heberti } \\
\text { Korovchinsky } 2002\end{array}$ & $\begin{array}{c}\text { Diaphanosoma } \\
\text { birgei Koøínek } \\
1981\end{array}$ & Korovchinsky 2002 & Yes & Yes & Yes \\
\hline Latona setifera O.F. Müller 1785 & & $\begin{array}{c}\text { Brooks 1959; Korovchinsky } \\
1992 \\
\end{array}$ & No & Yes & No \\
\hline $\begin{array}{l}\text { Latonopsis occidentalis Birge } \\
1892\end{array}$ & & Korovchinsky 1992 & No & Yes & Yes \\
\hline $\begin{array}{l}\text { Pseudosida bidentata Herrick } \\
1884\end{array}$ & & $\begin{array}{c}\text { Brooks 1959; Korovchinsky } \\
1992 \\
\end{array}$ & Yes & No & No \\
\hline $\begin{array}{l}\text { Sarsilatona serricauda Sars } \\
1901\end{array}$ & & Korovchinsky 1992 & Yes & No & No \\
\hline $\begin{array}{l}\text { Sida crystallina americana } \\
\text { Korovchinsky } 1979\end{array}$ & & Korovchinsky 1992 & No & Yes & No \\
\hline \multicolumn{6}{|l|}{ COPEPODA } \\
\hline \multicolumn{6}{|l|}{ Calanoida } \\
\hline Centropagidae & & & & & \\
\hline
\end{tabular}




\begin{tabular}{|c|c|c|c|c|c|}
\hline Taxon & Synonymy & References & $\begin{array}{l}\text { Wetland } \\
\text { Ponds }\end{array}$ & $\begin{array}{l}\text { Impound- } \\
\text { ments }\end{array}$ & $\begin{array}{l}\text { Small } \\
\text { Impound- } \\
\text { ments }\end{array}$ \\
\hline $\begin{array}{l}\text { Osphranticum labronectum S. } \\
\text { A. Forbes } 1882\end{array}$ & & Wilson 1959; Bayly 1992 & Yes & No & Yes \\
\hline \multicolumn{6}{|l|}{ Diaptomidae } \\
\hline $\begin{array}{l}\text { Aglaodiaptomus atomicus } \\
\text { DeBiase and Taylor } 1997\end{array}$ & & DeBiase and Taylor 1997 & Yes & No & No \\
\hline A. clavipoides Wilson 1955 & $\begin{array}{l}\text { Diaptomus } \\
\text { clavipoides }\end{array}$ & Wilson 1955; Wilson 1959 & Yes & No & No \\
\hline A. conipedatus Marsh 1907 & $\begin{array}{l}\text { Diaptomus } \\
\text { conipedatus }\end{array}$ & Wilson 1959 & Yes & No & No \\
\hline A. stagnalis S. A. Forbes 1882 & $\begin{array}{l}\text { Diaptomus } \\
\text { stagnalis }\end{array}$ & Wilson 1959 & Yes & No & No \\
\hline $\begin{array}{l}\text { Hesperodiaptomus augustaensis } \\
\text { Turner } 1910\end{array}$ & $\begin{array}{l}\text { Diaptomus } \\
\text { augustaensis }\end{array}$ & Turner 1910; Wilson 1959 & Yes & No & No \\
\hline $\begin{array}{l}\text { Leptodiaptomus moorei Wilson } \\
1954\end{array}$ & $\begin{array}{l}\text { Diaptomus } \\
\text { moorei }\end{array}$ & Wilson 1954; Wilson 1959 & Yes & No & No \\
\hline $\begin{array}{l}\text { Onychodiaptomus birgei Marsh } \\
1894\end{array}$ & $\begin{array}{l}\text { Diaptomus } \\
\quad \text { birgei }\end{array}$ & Wilson 1959 & Yes & Yes & Yes \\
\hline O. sanguineus S. A. Forbes 1876 & $\begin{array}{l}\text { Diaptomus } \\
\text { sanguineus }\end{array}$ & Wilson 1959 & Yes & No & No \\
\hline $\begin{array}{l}\text { Skistodiaptomus floridanus } \\
\text { Marsh } 1926\end{array}$ & $\begin{array}{l}\text { Diaptomus } \\
\text { floridanus }\end{array}$ & Wilson 1959 & Yes & No & No \\
\hline S. mississippiensis Marsh 1894 & $\begin{array}{c}\text { Diaptomus } \\
\text { mississippiensis }\end{array}$ & Wilson 1959 & No & Yes & Yes \\
\hline S. reighardi Marsh 1895 & $\begin{array}{l}\text { Diaptomus } \\
\text { reighbardi }\end{array}$ & Wilson 1959 & No & Yes & No \\
\hline S. pallidus Herrick 1879 & $\begin{array}{l}\text { Diaptomus } \\
\text { pallidus }\end{array}$ & Wilson 1959 & Yes & Yes & No \\
\hline \multicolumn{6}{|l|}{ Temoridae } \\
\hline $\begin{array}{l}\text { Epischura fluviatilis Herrick } \\
1883\end{array}$ & & Wilson 1959; Bowman 1991 & No & Yes & No \\
\hline Eurytemora affinis Poppe 1880 & & Wilson 1959 & No & Yes & No \\
\hline \multicolumn{6}{|l|}{ Cyclopoida } \\
\hline Cyclopidae & & Yeatman 1959; Einsle 1996 & Yes & No & No \\
\hline $\begin{array}{l}\text { Acanthocyclops carolineanus } \\
\text { Yeatman } 1944\end{array}$ & & $\begin{array}{c}\text { Yeatman 1944, 1959; Einsle } \\
1996\end{array}$ & Yes & No & No \\
\hline A. exilis Coker 1934 & & Yeatman 1959; Einsle 1996 & Yes & Yes & Yes \\
\hline $\begin{array}{l}\text { A. vernalis-robustus complex } \\
\text { Fischer } 1853\end{array}$ & & Yeatman 1959; Einsle 1996 & Yes & Yes & Yes \\
\hline $\begin{array}{l}\text { Diacyclops bicuspidatus } \\
\text { thomasi S. A. Forbes } 1882\end{array}$ & & Yeatman 1959 & Yes & No & No \\
\hline $\begin{array}{l}\text { D. crassicaudis brachycercus } \\
\text { Kiefer } 1929\end{array}$ & & Yeatman 1959; Reid 1992a & Yes & No & Yes \\
\hline D. haueri Kiefer 1931 & & Yeatman 1959 & Yes & No & No \\
\hline
\end{tabular}




\begin{tabular}{|c|c|c|c|c|c|}
\hline Taxon & Synonymy & References & $\begin{array}{l}\text { Wetland } \\
\text { Ponds }\end{array}$ & $\begin{array}{l}\text { Impound- } \\
\text { ments }\end{array}$ & $\begin{array}{l}\text { Small } \\
\text { Impound- } \\
\text { ments }\end{array}$ \\
\hline D. cf. languloides Lilljeborg 1901 & & Yeatman 1959 & Yes & No & No \\
\hline D. navus Herrick 1882 & & Yeatman 1959; Reid 1989 & Yes & No & No \\
\hline D. palustris Reid 1988 & & Reid 1988 & Yes & No & No \\
\hline $\begin{array}{l}\text { Ectocyclops phaleratus Koch } \\
1838\end{array}$ & & Yeatman 1959 & Yes & No & No \\
\hline Eucyclops agilis Koch 1838 & & Yeatman 1959 & Yes & No & Yes \\
\hline E. conrowae Reid 1992 & & Reid 1992b & Yes & No & Yes \\
\hline E. macrurus Sars 1863 & & Yeatman 1959 & Yes & No & No \\
\hline E. prionophorus & & $\begin{array}{l}\text { Yeatman 1959; Smith and } \\
\text { Fernando } 1977\end{array}$ & Yes & No & No \\
\hline E. speratus & & Yeatman 1959 & Yes & No & No \\
\hline $\begin{array}{l}\text { Macrocyclops albidus Jurine } \\
1820\end{array}$ & & Yeatman 1959 & Yes & No & Yes \\
\hline M. fuscus Jurine 1820 & & $\begin{array}{c}\text { Yeatman 1959; Dahms and } \\
\text { Fernando } 1994\end{array}$ & Yes & No & Yes \\
\hline $\begin{array}{l}\text { Megacyclops latipes Lowndes } \\
1927\end{array}$ & & $\begin{array}{c}\text { Yeatman 1959; Smith and } \\
\text { Fernando 1977; Einsle } 1996\end{array}$ & Yes & No & No \\
\hline $\begin{array}{l}\text { Mesocyclops americanus Dussart } \\
1985\end{array}$ & & $\begin{array}{l}\text { Dussart 1985; Ueda and Reid } \\
2003\end{array}$ & Yes & No & No \\
\hline M. edax Forbes 1891 & & $\begin{array}{c}\text { Yeatman 1959; Reid and } \\
\text { Moreno 1999; Ueda and Reid } \\
2003\end{array}$ & Yes $^{\mathrm{r}}$ & Yes & Yes \\
\hline Microcyclops sp. & & J.W. Reid, pers. comm. & Yes & No & Yes \\
\hline $\begin{array}{l}\text { Paracyclops canadensis Willey } \\
1934\end{array}$ & & Karaytug 1999 & Yes & No & Yes \\
\hline $\begin{array}{l}\text { Orthocyclops modestus } \text { Herrick } \\
1883\end{array}$ & & Yeatman 1959 & Yes & No & No \\
\hline $\begin{array}{l}\text { Tropocyclops extensus Dussart } \\
\text { and Fernando } 1990\end{array}$ & & $\begin{array}{l}\text { Dussart and Fernando 1990; } \\
\text { Reid } 1991\end{array}$ & Yes & No & No \\
\hline $\begin{array}{l}\text { T. prasinus mexicanus Kiefer } \\
1938\end{array}$ & & Yeatman 1959; Reid 1991 & Yes & Yes & Yes \\
\hline
\end{tabular}

${ }^{a}$ Reported from Par Pond (Berner 1982).

${ }^{\mathrm{b}}$ Reported from Pond C (Taylor and Mahoney 1988).

${ }^{\mathrm{r}}$ Rare species, occurring only in one site.

** These species were collected in Bays 5092 and 5184 during April, 2003. They were absent during June, 2003. They occurred during an abnormally wet period following hydrologic restoration. Both ponds are near L Lake, where both species occur. We question whether these two species will permanently colonize the wetland ponds. 
Notes on undescribed species of cladocerans and copepods from the Savannah River Site.

Species that do not completely fit the descriptions of currently named species are desgnated with "sp." Those with "cf." designations are generally part of a species complex that is currently not taxonomically defined, or they may very closely resemble a European congener, but have not been thoroughly examined in North America.

\begin{tabular}{|c|c|c|}
\hline Species & Closest Congener and Characteristics & Differing Characteristics \\
\hline Acroperus sp. & $\begin{array}{l}\text { A. harpae: Postabdomen with 11-12 } \\
\text { lateral fascicles. }\end{array}$ & $\begin{array}{l}\text { Postabdomen with 16-17 lateral fascicles. Designated "sp." by D. } \\
\text { Frey. Frey (pers. comm. to D.L. Mahoney) notes this genus has } \\
\text { not been defined in North America. Hence, no specific names can } \\
\text { be given. }\end{array}$ \\
\hline Alonella cf. excisa & $\begin{array}{l}\text { Alonella excisa: Dorsal margin } \\
\text { of carapace moderately arched. } \\
\text { Ventroposterior angle with deep notch. }\end{array}$ & $\begin{array}{l}\text { Dorsal margin of carapace slightly curved. Ventroposterior angle } \\
\text { with shallow or no notch. B. Hann (pers.com. to AED) notes that } \\
\text { this species is a widely-distributed but not-yet-described species. }\end{array}$ \\
\hline Camptocercus sp. & $\begin{array}{l}\text { Camptocercus rectirostris: } \\
\text { Postabodomen with } 15-17 \text { marginal } \\
\text { denticles }\end{array}$ & $\begin{array}{l}\text { Postabdomen with } 20 \text { marginal and about as many lateral } \\
\text { denticles. Designated "sp." by D. Frey. He notes (pers. comm. to } \\
\text { D.L. Mahoney) this genus has not been defined in North America. } \\
\text { Hence, no specific names can be given. }\end{array}$ \\
\hline $\begin{array}{l}\text { Ceriodaphnia cf. } \\
\text { cornuta }\end{array}$ & $\begin{array}{l}\text { Ceriodaphnia cornuta: Rostral beak } \\
\text { present. }\end{array}$ & $\begin{array}{l}\text { Lacks rostral beak. Dorso-lateral ridge along ephippium. D. } \\
\text { Berner (pers. com to AED) designated this species as a complex } \\
\text { in need of further work. }\end{array}$ \\
\hline Ceriodaphnia cf. dubia & $\begin{array}{l}\text { Ceriodaphnia dubia: High, slightly } \\
\text { pointed posteriordorsal angle. Spinules } \\
\text { of the proximal pecten are noticeably } \\
\text { shorter than those on the central } \\
\text { pecten. }\end{array}$ & $\begin{array}{l}\text { Heads not fully depressed and somewhat smaller than } C \text {. dubia, } \\
\text { with lower and more pointed posteriodorsal angle. This species } \\
\text { has long, plumose ventral setae that are not found in } C \text {. dubia. } \\
\text { Spinules of the central pecten are heavy and about the same size } \\
\text { as those of the adjacent pectens. D. Berner (pers. com. to AED) } \\
\text { believes } C \text {. dubia to be "a complex of morphologically poorly } \\
\text { differentiated species, and that it is best to call most of them cf. } \\
\text { dubia for the time being." }\end{array}$ \\
\hline Ceriodaphnia sp. & $\begin{array}{l}\text { Ceriodaphnia pulchella: Postabdomen } \\
\text { with accessory set of denticles between } \\
\text { the proximal anal denticles. (See } \\
\text { Pennak 1989) }\end{array}$ & $\begin{array}{l}\text { Lacks accessory denticles between the proximal anal denticles. } \\
\text { Designated "sp." by D. Berner (pers. comm. to AED). }\end{array}$ \\
\hline Chydorus spp. 1 and 3 & Chydorus sphaericus & $\begin{array}{l}\text { D. Frey (1980) also notes that Chydorus sphaericus is actually } \\
\text { a complex of species, and that } C \text {. sphaericus itself is relatively } \\
\text { uncommon in North America. }\end{array}$ \\
\hline $\begin{array}{l}\text { Diaphanosoma } \mathrm{cf} . \\
\text { beberti }\end{array}$ & Diaphanosoma birgei & $\begin{array}{l}\text { Most of the description fits this species, however, distal spinules } \\
\text { of the antennal basipodite more closely resemble } D \text {. frey } i \text {. }\end{array}$ \\
\hline $\begin{array}{l}\text { Lathonura } \mathrm{cf} . \\
\text { rectirostris }\end{array}$ & $\begin{array}{l}\text { Lathonura rectirostris: No antennal } \\
\text { spines. No spine next to ocellus }\end{array}$ & $\begin{array}{l}\text { Postabdomen not as in L. rectirostris, which is the sole described } \\
\text { species of this genus. } 2 \text { antennal spines, spine next to ocellus. }\end{array}$ \\
\hline Macrothrix sp. & & $\begin{array}{l}\text { Does not match any descriptions. Shape most closely resembles } \\
\text { M. spinosa, but carapace is somewhat reticulated with small } \\
\text { hooked spines. Antennules serrated as in M. superaculeata. }\end{array}$ \\
\hline Microcyclops sp. & $\begin{array}{l}\text { Microcyclops varicans and } M . \\
\text { rubellus }\end{array}$ & $\begin{array}{l}\text { J. Reid (pers. comm. to AED) commented that unpublished } \\
\text { observations on comparisons of North American and Eurasian } \\
\text { Microcyclops by Iskandar Mirabdullayev suggest that North } \\
\text { American morphs do not resemble either Eurasian species, } M \text {. } \\
\text { varicans or } M \text {. rubellus. She recommended using "Microcyclops } \\
\text { sp." until this genus is better characterized. }\end{array}$ \\
\hline
\end{tabular}




\section{Other notes:}

Acanthocyclops vernalis/robustus complex-Einsle (1996) noted that of the cyclopoid copepod referred to as "A. vernalis" in North America is actually several distinct species, all of which are different from the European A. vernalis. This species is taxonomically nearly identical to A. robustus, but with subtle morphological differences. Dodson et al. (2003) observed that $A$. robustus is also probably several distinct cryptic species. Furthermore, Hudson et al. (1998) note that the North American A. vernalis is a temporary pond species.

Diapbanosoma-Korovchinsky (2002) indicated that a widespread misinterpretation of the species composition of this genus in North America has been due to a tradition of basing species descriptions on those of two European species, $D$. brachyurum and D. birgei. His ongoing revision of the genus indicates that North America has a high species richness, especially in the southern United States, where tropical forms (including D. fluviatile and D. brevireme) are common. He notes that additional species will likely be described.

Latonopsis-Korovchinsky (1992) includes this species in a group of poorly described forms designated "L. australis group", which is in need detailed revision. 


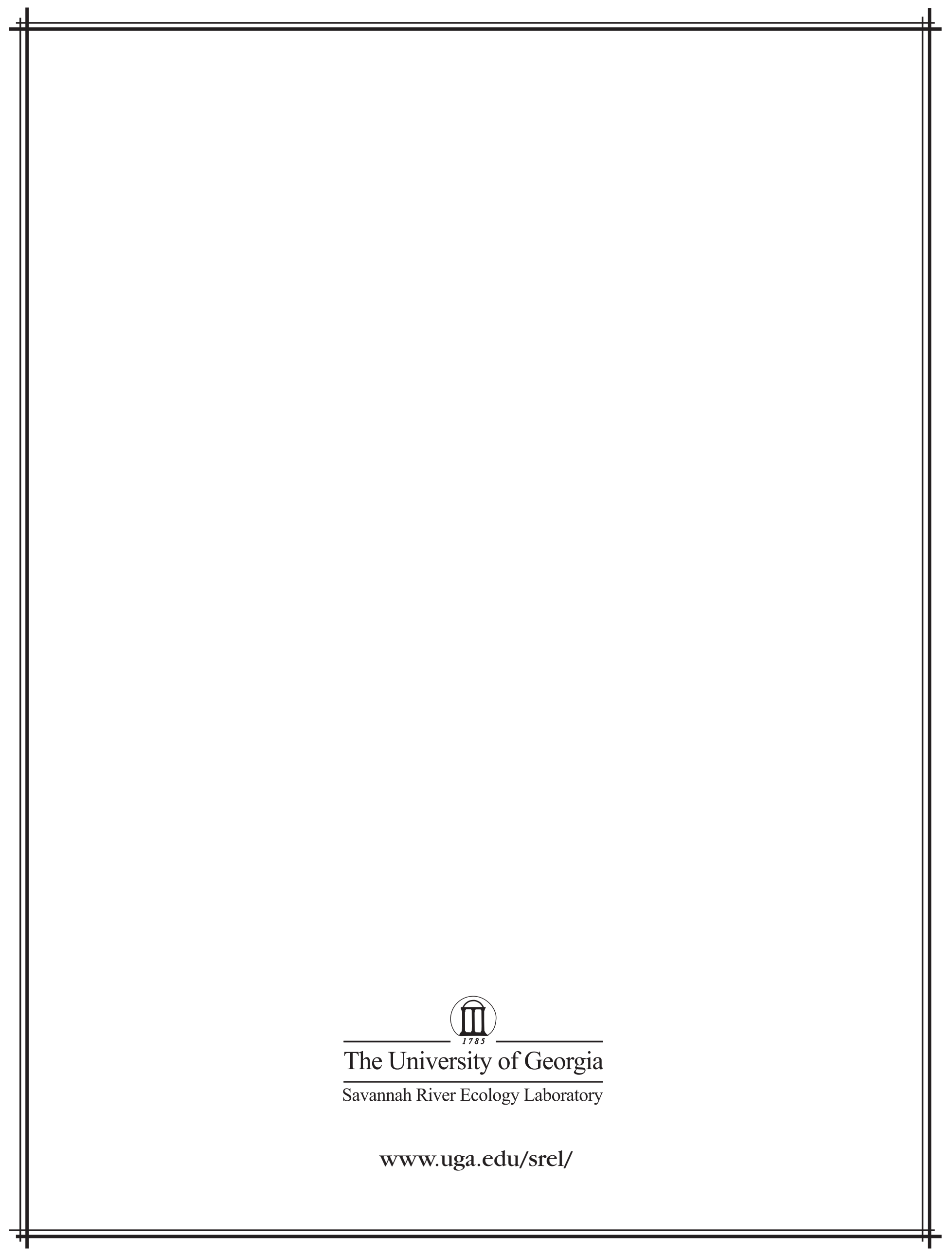

